Prepared for the U.S. Department of Energy

under Contract DE-AC05-76RL01830

\title{
Effect of Concrete Waste Form Properties on Radionuclide Migration
}
DM Wellman
KE Parker
CC Bovaird
RM Ermi
SV Mattigod
MI Wood

September 2008

Pacific Northwest

NATIONAL LABORATORY 


\title{
DISCLAIMER
}

This report was prepared as an account of work sponsored by an agency of the United States Government. Neither the United States Government nor any agency thereof, nor Battelle Memorial Institute, nor any of their employees, makes any warranty, express or implied, or assumes any legal liability or responsibility for the accuracy, completeness, or usefulness of any information, apparatus, product, or process disclosed, or represents that its use would not infringe privately owned rights. Reference herein to any specific commercial product, process, or service by trade name, trademark, manufacturer, or otherwise does not necessarily constitute or imply its endorsement, recommendation, or favoring by the United States Government or any agency thereof, or Battelle Memorial Institute. The views and opinions of authors expressed herein do not necessarily state or reflect those of the United States Government or any agency thereof.

\author{
PACIFIC NORTHWEST NATIONAL LABORATORY \\ operated by \\ BATTELLE \\ for the \\ UNITED STATES DEPARTMENT OF ENERGY \\ under Contract DE-AC05-76RL01830
}

Printed in the United States of America

Available to DOE and DOE contractors from the

Office of Scientific and Technical Information,

P.O. Box 62, Oak Ridge, TN 37831-0062;

ph: (865) 576-8401

fax: (865) 576-5728

email: reports@adonis.osti.gov

\author{
Available to the public from the National Technical Information Service, \\ U.S. Department of Commerce, 5285 Port Royal Rd., Springfield, VA 22161 \\ ph: (800) 553-6847 \\ fax: (703) 605-6900 \\ email: orders@ntis.fedworld.gov \\ online ordering: http://www.ntis.gov/ordering.htm
}

This document was printed on recycled paper.

$(9 / 2003)$ 


\title{
Effect of Concrete Waste Form Properties on Radionuclide Migration
}

\author{
DM Wellman KE Parker \\ CC Bovaird RM Ermi \\ SV Mattigod MI Wood
}

September 2008

Prepared for

the U.S. Department of Energy

under Contract DE-AC05-76RL01830

Pacific Northwest National Laboratory

Richland, Washington 99352 



\section{Executive Summary}

Assessing long-term performance of Category 3 waste cement grouts for radionuclide encasement requires knowledge of the radionuclide-cement interactions and mechanisms of retention (i.e., sorption or precipitation). This knowledge will enable accurate prediction of radionuclide fate when the waste forms come in contact with groundwater. Numerous sets of concrete-soil half-cell tests were initiated in fiscal year (FY) 2008 to quantify 1) diffusion of iodine (I) and technetium (Tc) from concrete into uncontaminated soil after 1 and 2 years, 2) I and rhenium (Re) (set 1) and Tc (set 2) diffusion from fractured concrete into uncontaminated soil, and 3) evaluate the moisture distribution profile within the sediment half-cell. These half-cells will be sectioned in FY 2009 and FY 2010.

In FY 2008, concrete-soil half-cells initiated during FY 2007 using fractured concrete prepared with and without metallic iron, half of which were carbonated, were sectioned to evaluate the diffusion of I and $\mathrm{Re}$ in the concrete part of the half-cell. One half of the concrete half-cell was sectioned parallel to the concrete-soil interface, while the other half was sectioned parallel to the concrete monolith fracture (perpendicular to the concrete-soil interface). It was observed from the half of the concrete monolith, sectioned parallel to the concrete-soil interface, that the concentrations of I and Re quantified within the monoliths at $7 \%$ and $15 \%$ moisture content which were not carbonated, were lower than the interfacial concentration measured at $4 \%$ moisture content. The concentrations of I and Re were greatest within the first $5 \mathrm{~mm}$ and displayed an asymptotic decrease in concentration at $4 \%$ and $7 \%$ moisture content. At $15 \%$ moisture content, however, the initial concentration of I and Re decreases rapidly over the first $5 \mathrm{~mm}$ to a relative steady-state concentration of $\sim 8 \mathrm{mg} / \mathrm{g}$, which is sustained throughout the extent of the monolith. The interfacial concentration of I and Re at 4\%, 7\%, and 15\% moisture content were comparable, irrespective of moisture content, for carbonated concrete monoliths. However, the overall diffusion of I and Re is greater in carbonated rather than non-carbonated concrete monoliths. At 4\% moisture content there was no measureable effect of iron on the diffusion of I or Re. At 7\%, however, the diffusion of I and Re were greatest in the absence of iron. The behavior of I and Re at $15 \%$ moisture content is comparable to that of the non-carbonated monolith. There was no measurable affect of iron on the diffusion of iodine.

The behavior of I and Re within concrete sections taken perpendicular to the concrete-soil interface (parallel to the fracture) was markedly different relative to those sectioned parallel to the concrete-soil interface. Diffusion of I and Re in the presence of iron, in non-carbonated cores was comparable at 7\% and $15 \%$ moisture content. At $4 \%$ moisture content, however, the diffusion of I and Re rapidly decreased to a sustained mass of $\sim 2 \mathrm{mg} / \mathrm{g}$ throughout the concrete profile. The behavior of I and Re in noncarbonated monoliths that do not contain iron is comparable at $4 \%$ and $15 \%$ moisture content to that observed in the presence of iron. However, at $7 \%$ moisture content the concentration of $I$ and $R e$ is $\sim 1 \mathrm{mg} / \mathrm{g}$ throughout the monolith profile, substantially less than the sustained concentration of $\sim 5 \mathrm{mg} / \mathrm{g}$ measured in the presence of iron. Results presented here are in agreement with previous findings that suggested 1) a direct relationship between diffusion within concrete monoliths and the degree of moisture

content and 2) the inclusion of iron results in the formation of microcracks that can facilitate diffusion. In carbonated concrete monoliths, the behavior of I and Re was comparable to that observed in noncarbonated monoliths with a noted exception at $7 \%$ moisture content. At $7 \%$ moisture content, the diffusion of I and Re was greater in the absence of iron, rather than in the presence of iron. Comparable behavior was observed for the other half of this monolith that was sectioned parallel to the concrete-soil interface. 
A second set of diffusion experiments which had been initiated during FY 2007 using concrete-soil half-cells containing Tc was sectioned in FY 2008 to measure the diffusion profile in the soil half-cell. These half-cells were prepared with and without metallic iron and set up under unsaturated conditions (4\%, $7 \%$, and $15 \%$ by wt moisture content). The Tc concentration profile for sediments at $4 \%$ and $7 \%$ moisture content exhibited greater concentrations for those in contact with concrete cores without iron. Contrary to the soil profile for Tc at 4\% moisture content, at $7 \%$ the concentration of Tc in the sediment displayed a slight increase as a function of increasing distance from the concrete-soil interface. This slight increase through the soil profile also was observed for the concrete-soil half-cell at $7 \%$ moisture content for the concrete containing iron. In the presence of iron, the concentration of Tc increased over the length of the half-cell. The concentration of Tc throughout the soil profile was $\sim 65 \%$ lower in the concrete-soil half-cell that contained iron in the concrete monolith than in that which did not contain iron at $7 \%$ moisture content. The concentration profiles for sediments at $15 \%$ moisture content displayed an increase in concentration within the first $4 \mathrm{~cm}$ of the soil profile and then a general decrease in Tc concentration. The concentration of Tc in the soil from the concrete-soil half-cell that contained iron in the concrete monolith was greater than in that which did not contain iron.

The total concentration of Tc recovered in the concrete half-cells was comparable for concrete monoliths containing iron and those without iron. The concentration profiles for concrete half-cells indicate greater concentrations of Tc for half-cells in which the concrete did not contain iron. At 4\% moisture content the concentration profile for Tc in the absence of iron displays a linear decrease over the first $10 \mathrm{~mm}$ of the monolith, followed by a more gradual decrease over the subsequent $10 \mathrm{~mm}$ of concrete monolith. A similar behavior is observed in the presence of iron, except that the concentration of Tc within the monolith is less than that measured in the presence of iron. The distribution and behavior of Tc was similar for concrete monoliths at $7 \%$ and $15 \%$ moisture content. In the absence of iron, the concentration near the interface was $\sim 0.3 \mu \mathrm{g} \mathrm{Tc} / \mathrm{g}$ concrete. The concentration of Tc decreased slightly throughout the length of the cores to $\sim 0.2 \mu \mathrm{g} \mathrm{Tc} / \mathrm{g}$ concrete. In the presence of iron, the concentration near the interface was $\sim 0.25$ to $0.3 \mu \mathrm{g} \mathrm{Tc} / \mathrm{g}$ concrete. The concentration again decreased throughout the length of the core, but the decrease was greater than in the absence of iron. In the presence of iron, the concentration decreased to a minimum of $\sim 0.15 \mu \mathrm{g}$ Tc/g concrete, 10 to $15 \mathrm{~mm}$ from the concrete-soil interface. These results contrast those previous presented by Mattigod et al. (2001), which quantified the diffusion of I and Tc from concrete monoliths containing iron at 4\% and 7\% moisture contents, sampling at 64 and 169 days. Results by Mattigod et al. (2001) indicated the inclusion of iron did not significantly influence the diffusion of I or Tc and/or Re. The significantly short test duration for previous half-cell experiments may have limited the observed affect of iron on Tc diffusion. This will be confirmed by the two sets of half-cell tests initiated in FY 2008 that will continue for test periods of 1 and 2 years.

A study was initiated during FY 2004 to better understand the reactivity of limited solubility uranium(VI) (U(VI) -bearing compounds in Portland cement grout specimens. The U(VI) nitrate-spiked specimens were aged for various time spans ranging from 2 weeks to 1 year. The uranium phases in these specimens were identified to be soddyite, becquerelite, uranophane, and autunite. Reliable thermochemical data are not available for these phases under conditions present in concrete waste forms. Therefore, to gather such data, synthetic routes were developed for the precipitation of pure uranium phases. From FY 2007 to FY 2008, the solubility measurements of these U-solid phases were completed under concrete porewater conditions. Although confirmation of secondary phases is still necessary, preliminary results suggest the formation of 1) a calcium-uranium oxide from the reaction of becquerlite, 2) uranophane group minerals from the reaction of soddyite, and 3) mixed sodium-calcium uranium 
phosphate secondary phases from the reaction of autunite in simulated Portland cement-equilibrated porewater. Completion of analytical analyses to quantify aqueous cations and anions, coupled with geochemical thermodynamic modeling will aid in further understanding the stability and long-term control of uranium provided by concrete waste forms. However, it is suggested here that 1) the release of uranium from the degradation of uranium oxyhydroxides will be controlled by the formation of secondary uranium oxides; 2) regardless of the replacement of soddyite by uranophane, uranyl-silicate phases will persist within concrete waste forms; and 3) the release of uranium from the degradation of uraniumphosphate phases will be controlled by the formation of secondary uranyl-phosphate phases. During FY 2009 , these data will be analyzed to generate improved input for performance assessment modeling of uranium releases from wasteform concrete. 



\section{Acknowledgments}

The authors thank SR Baum and ET Clayton for conducting inductively coupled plasma (ICP)-optical emission spectrometry and ICP-mass spectrometry analyses, respectively. 



\section{Acronyms and Abbreviations}

$\begin{array}{ll}\text { BFS } & \text { blast furnace slag } \\ \text { EDS } & \text { energy dispersive spectrometer } \\ \text { FY } & \text { fiscal year } \\ \text { I } & \text { iodine } \\ \text { ICP-MS } & \text { inductively coupled plasma-mass spectrometry } \\ \text { ICP-OES } & \text { inductively coupled plasma-optical emission spectrometry } \\ \text { L } & \text { limestone } \\ \text { MC } & \text { moisture content } \\ \text { OPC } & \text { ordinary Portland cement } \\ \text { PVC } & \text { polyvinyl chloride } \\ \text { Re } & \text { rhenium } \\ \text { RNIP } & \text { reactive nanoscale zero valent iron particles } \\ \text { Se } & \text { selenium } \\ \text { SEM } & \text { scanning electron microscopy } \\ \text { SRPC } & \text { sulfate-resistant Portland cement } \\ \text { Tc } & \text { technetium } \\ \text { U(VI) } & \text { uranium (VI) }\end{array}$





\section{Contents}

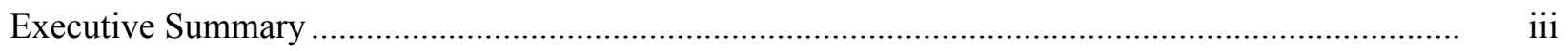

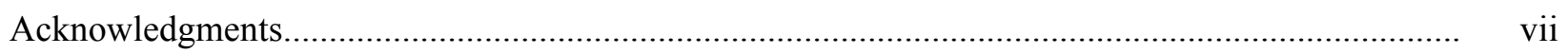

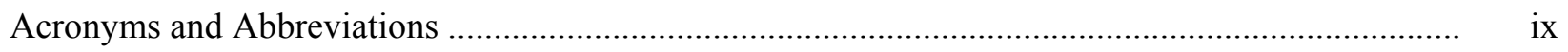

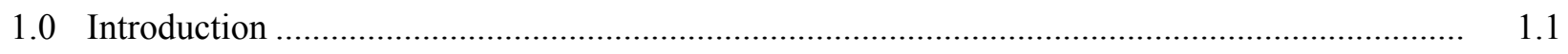

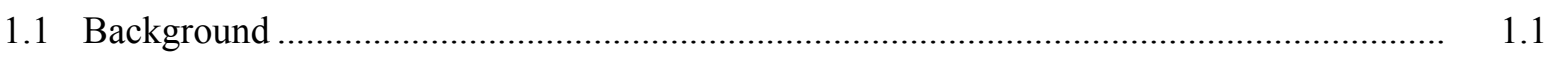

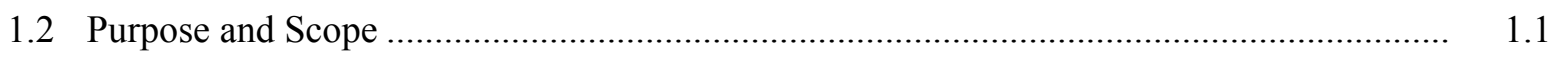

1.3 Report Contents and Organization ............................................................................. 1.2

2.0 Determining the Rate of Concrete Carbonation under Simulated Vadose-Zone Conditions at Hanford Site............................................................................................................ 2.1

3.0 Concrete-Soil Half-Cell Experiments to Determine the Effects of Concrete Carbonation and Collodial Iron on the Diffusion of Technetium ................................................................... 3.1

3.1 Specified Concrete Composition for Encasement ........................................................... 3.1

3.2 Materials and Laboratory-Scale Mixture Design .......................................................... 3.2

3.3 Concrete Mix and Specimen Preparation.................................................................... 3.2

4.0 Concrete-Soil Half-Cell Experiments to Determine the Diffusion of Iodine and Rhenium

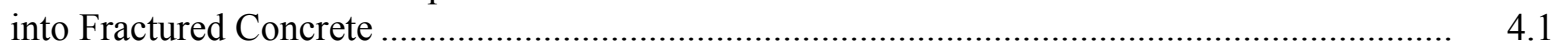

4.1 Concentration Profile Results and Discussion .......................................................... 4.2

5.0 Concrete-Soil Half-Cell Experiments to Determine the Diffusion of Iodine, Rhenium, and Technetium from Fractured Concrete into Soil .................................................................... 5.1

6.0 Moisture Gradient Within Concrete-Soil Half-Cell Tests ..................................................... 6.1

7.0 Concrete-Soil Half-Cell Experiments to Determine the Effects of Iron on the Diffusion of

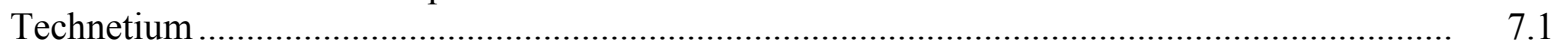

7.1 Concentration Profile Results and Discussion ............................................................ $\quad 7.2$

8.0 Reactivity of Limited Solubility U(VI)-Bearing Compounds in Concrete ............................... 8.1

8.1 Synthesis of U(VI) Phases........................................................................................ 8.1

8.1.1 Becquerelite Precipitation ........................................................................... 8.1

8.1 .2 Soddyite Precipitation ................................................................................. 8.1

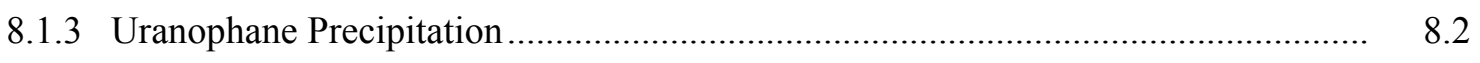

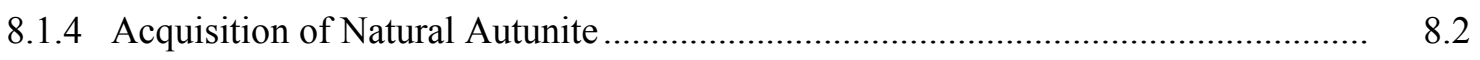

8.2 Characterization of U(VI) Phases............................................................................. 8.2

8.2 .1 X-Ray Diffraction ....................................................................................... 8.2

8.2.2 Scanning Electron Microscopy-Energy Dispersive Spectrometry …....................... 8.2

8.3 Solubility Testing of U(VI) Minerals ......................................................................... 8.3

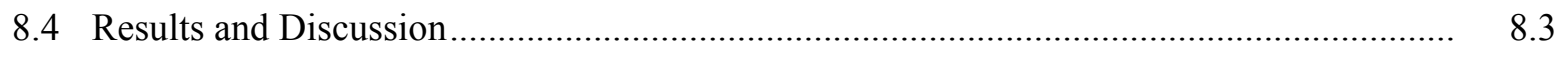

8.4.1 Characterization of U(VI) Phases.................................................................. 8.3

8.4.2 Solubility Testing of U(VI) Minerals ................................................................ 8.5

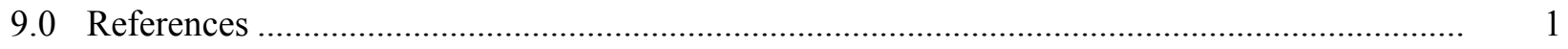




\section{Figures}

4.1 Mechanism for Soil Sampling from a Concrete-Soil Diffusion Half-Cell, Soil Sampling from a Diffusion Half-Cell.

4.2 Concentration Profiles for Soil Half-Cell I and Re Profiles.....................................................

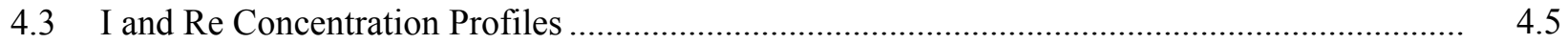

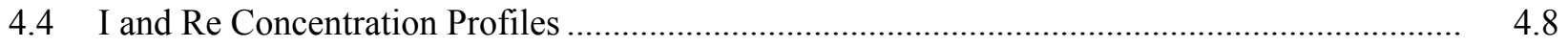

7.1 Concentration Profiles for Soil Half-Cell Tc Profiles .............................................................

7.2 Concentration Profiles for Concrete Half-Cell Tc Profiles ......................................................

8.1 X-ray Diffraction Pattern for Becquerelite, Soddyite, and Uranophane .................................. 8.4

8.2 Scanning Electron Photomicrographs of Becquerelite, Soddyite, and Uranophane. ................. 8.5

8.3 Solubility of Becquerlite in Simulated Portland Cement-Equilibrated Waters......................... 8.6

8.4 Scanning-Electron Photomicrographs of Solids Material from the Reaction of Becquerlite in Harwell Porewater Displaying the Formation of Poorly Crystalline, Mixed Sodium- and Calcium-Oxyhydroxide Phase on the Surface of Becquerlite Crystals..................................... 8.6

8.5 Solubility of Soddyite in Simulated Portland Cement-Equilibrated Waters ............................. 8.7

8.6 Scanning-Electron Photomicrographs of Solids Material from the Reaction of Soddyite in Harwell Porewater.....

8.7 Scanning-Electron Photomicrographs of Solids Material from the Reaction of Soddyite in OPC/L Porewater Displaying the Formation of Acicular, Fibrous Coarse-Grained Tuffs ......... $\quad 8.8$

8.8 Solubility of Uranophane in Simulated Portland Cement-Equilibrated Waters........................ 8.8

8.9 Scanning-Electron Photomicrographs of Solids Material from the Reaction of Uranophane in 9:1 BFS/OPC Porewater Displaying the Formation of Acicular, Fibrous Fine-Grained Crystal Tuffs

8.10 Solubility of Autunite in Simulated Portland Cement-Equilibrated Waters

8.11 Scanning-Electron Photomicrographs of Solids Material from the Reaction of Autunite in $\mathrm{OPC} / \mathrm{BFS} / \mathrm{L}$ Porewater.

8.12 Percent Distribution of $\mathrm{U}^{6+}-\mathrm{H}_{2} \mathrm{O}$ System at $25^{\circ} \mathrm{C}, \mathrm{I}=0.1 \mathrm{M}, \mathrm{P}_{\mathrm{CO} 2}=0$ bar and $\Sigma \mathrm{U}^{6+}=10^{-6} \mathrm{M}$ in the Absence of Complexing Ligands Other than Hydroxide

8.13 Percent Distribution of $\mathrm{U}^{6+}$ Species Calculated Using MINTEQA2 at $25^{\circ} \mathrm{C}, \mathrm{I}=0.1 \mathrm{M}$, and $\mathrm{pCO}_{2}=10^{-3.5}$ bar for $\sum \mathrm{U}^{6+}=10^{-6} \mathrm{M}$.

8.14 Percent Distribution of $\mathrm{U}^{6+}$ Aqueous Species Calculated Using MINTEQA2 in Hanford Groundwater Well-699-S3-25.

\section{Tables}

3.1 Material Specifications and Composition

3.2 Laboratory-Scale Material Specification and Composition ............................................... 3.2

3.3 Characteristics of Concrete Specimens Used in Concrete-Soil Half-Cells ............................... 3.3

4.1 Characteristics of Cement Specimens Used in Fractured Concrete-Soil Half-Cell Tests ........... 4.1 
4.2 Concentration of Iodine and Rhenium for Soil Half-Cell Profiles at 4\%, 7\%, and 15\% Moisture Content

4.3 Concentration of Iodine and Rhenium for Concrete Half-Cell Profiles at 4\%, 7\%, and 15\% Moisture Content Sectioned Parallel to the Concrete-Soil Interface

4.4 Concentration of Iodine and Rhenium for Concrete Half-Cell Profiles at 4\%, 7\%, and 15\% Moisture Content Sectioned Perpendicular to the Concrete-Soil Interface

5.1 Characteristics of Concrete Specimens Used in Concrete-Soil Half-Cells .............................. 5.2

6.1 Characteristics of Cement Specimens Used in Fractured Concrete-Soil Half-Cell Tests........... $\quad 6.1$

7.1 Characteristics of Cement Specimens Used in Fractured Concrete-Soil Half-Cell Tests........... 7.1

7.2 Concentration of Technetium for Soil Half-Cell Profiles at 4\%, 7\%, and 15\% Moisture Content.

7.3 Concentration of Technetium for Concrete Half-Cell Profiles at 4\%, 7\%, and 15\% Moisture Content

8.1 Chemical Composition of Portland Cement-Equilibrated Waters 


\subsection{Introduction}

\subsection{Background}

One of the methods being considered for safely disposing of Category 3 low-level radioactive wastes is to encase the waste in concrete. Such concrete encasement would contain and isolate the waste packages from the hydrologic environment and would act as an intrusion barrier. The current plan for waste isolation consists of stacking low-level waste packages on a trench floor, surrounding the stacks with reinforced steel, and encasing these packages in concrete. These concrete-encased waste stacks are expected to vary in size with maximum dimensions of $6.4 \mathrm{~m}$ long, $2.7 \mathrm{~m}$ wide, and $4 \mathrm{~m}$ high. The waste stacks are expected to have a surrounding minimum thickness of $15 \mathrm{~cm}$ of concrete encasement. These concrete-encased waste packages are expected to withstand environmental exposure (solar radiation, temperature variations, and precipitation) until an interim soil cover or permanent closure cover is installed, and to remain largely intact thereafter.

Any failure of concrete encasement may result in water intrusion and consequent mobilization of radionuclides from the waste packages. The mobilized radionuclides may escape from the encased concrete by mass flow and/or diffusion and move into the surrounding subsurface environment. Therefore, it is necessary to assess the performance of the concrete encasement structure and the ability of the surrounding soil to retard radionuclide migration. The retardation factors for radionuclides contained in the waste packages can be determined from measurements of diffusion coefficients for these contaminants through concrete and fill material.

The radionuclides iodine-129 $\left({ }^{129} \mathrm{I}\right)$, selenium-75 $\left({ }^{75} \mathrm{Se}\right)$, technetium-99 $\left({ }^{99} \mathrm{Tc}\right)$, and uranium-238 $\left({ }^{238} \mathrm{U}\right)$ are identified as long-term dose contributors in Category 3 waste (Mann et al. 2001; Wood et al. 1995). Because of their anionic nature in aqueous solutions, ${ }^{129} \mathrm{I},{ }^{75} \mathrm{Se},{ }^{99} \mathrm{Tc}$, and carbonate-complexed ${ }^{238} \mathrm{U}$ may readily leach into the subsurface environment (Serne et al. 1993, 1992, 1989, and 1995). The leachability and/or diffusion of radionuclide species must be measured to assess the long-term performance of waste grouts when contacted with vadose-zone porewater or groundwater.

\subsection{Purpose and Scope}

The objective of the investigation reported here was to initiate numerous sets of concrete-soil half-cell tests to 1) quantify the diffusion of I and Tc from concrete into uncontaminated soil after 1 and 2 years, 2) quantify I and Re (set 1) and Tc (set 2) diffusion from fractured concrete into uncontaminated soil, and 3) evaluate the moisture distribution profile within the sediment half-cell. These half-cells will be sectioned in fiscal year (FY) 2009 and FY 2010. Additionally, 1) concrete-soil half-cells initiated during FY 2007 using fractured concrete, prepared with and without metallic iron, and of which half were carbonated, were sectioned to evaluate the diffusion of I and Re in the concrete part of the half-cell under unsaturated conditions ( $4 \%, 7 \%$, and $15 \%$ moisture content by wt); 2$)$ concrete-soil half-cells containing Tc were sectioned to measure the diffusion profile in the soil half-cell unsaturated conditions $(4 \%, 7 \%$, and $15 \%$ by wt moisture content); and 3) solubility measurements of uranium solid phases were completed under concrete porewater conditions. 


\subsection{Report Contents and Organization}

The ensuing sections of this report present the results of the concrete-soil half-cell tests. As reported in Section 2.0, cement specimens prepared and encased in soil samples from the Hanford Site during FY 2005 are being tested at three different soil moisture contents to determine the rate of concrete carbonation under simulated vadose-zone conditions at Hanford Site. Section 3.0 describes the diffusion experiments initiated during FY 2008 to determine the effects of concrete carbonation and collodial iron on the diffusion of technetium using carbonated concrete-soil half-cells prepared with and without metallic iron, half of which were carbonated using carbonate solution. Section 4.0 describes the diffusion experiments initiated during FY 2007 using fractured concrete-soil half-cells to determine the diffusion of I and Re into fractured concrete, while Section 5.0 describes the diffusion experiments initiated during FY 2008 using fractured concrete-soil half-cells to determine the diffusion of I, Re, and Tc from fractured concrete into soil. The set of experiments initiated during FY 2008 to determine the moisture gradient within concrete-soil half-cells is described in Section 6.0, and the set of diffusion experiments initiated during FY 2007 using concrete-soil half-cells containing Tc to determine the effects of iron on the diffusion of technetium is described in Section 7.0. Finally, Section 8.0 describes the analysis of aged Portland cement grout specimens prepared with a uranium(VI) nitrate spike during FY 2004 to identify the uranium-bearing compounds that formed in the specimens. 


\subsection{Determining the Rate of Concrete Carbonation under Simulated Vadose-Zone Conditions at Hanford Site}

A number of cement specimens were prepared and encased in soil samples from the Hanford Site during FY 2005. Samples are being tested at three different soil moisture contents $(4 \%, 7 \%$, and $15 \%$ by mass) that reflect the vadose-zone conditions at Hanford. The soil-encased cement specimens were sealed to prevent moisture loss and aged for various time periods ranging from 6 months to 3 years. At the end of each aging period, three encased cement specimens (one from each moisture content category) are removed and analyzed to determine the depth of carbonation. Microscopic analyses are being conducted to assess the rate of expected microcracking and concomitant increase in the rate of radionuclide diffusion from the low-level waste and mixed low-level waste concrete.

During FY 2006, the first set of concrete monoliths (aged 6 months) were removed and analyzed for carbonation and microcracking. Microscopic analyses revealed no indication of microcracking. Moreover, the extent of carbonation was minimal. It was decided the next set of concrete monoliths would be removed for analyses after a period of 1 year from that time. The results of carbonation, petrographic microscopy, and scanning electron microscopy analyses indicated there was no substantial microcracking after nearly 2 years of aging (Wellman et al. 2007b). The final set of monoliths will be removed mid-year in FY 2009. 


\subsection{Concrete-Soil Half-Cell Experiments to Determine the Effects of Concrete Carbonation and Collodial Iron on the Diffusion of Technetium}

Two sets of diffusion experiments were initiated during FY 2008 using carbonated concrete-soil halfcells. These half-cells were prepared with and without metallic iron, and half of these were carbonated using carbonate solution. The tests were set up under unsaturated conditions (4\%, 7\%, and 15\% moisture content by weight). Soil half-cell specimens were spiked with I and Tc to achieve a measurable diffusion profile in the concrete part of the half-cell. Experimental conditions in these tests are similar to the concrete-soil and soil-soil half-cell experiments conducted previously (FY 1998 through 2007). In FY 2009 and FY 2010, one set of the soil and concrete half-cells will be sectioned and subjected to 1:1 water extractions to measure the concentration of I and Tc using inductively coupled plasma-mass spectrometry (ICP-MS), respectively, in soil and concrete thin slices. From the concentration data, probit plots will be constructed and the diffusion coefficients for these contaminants determined. We will correlate the calculated diffusion coefficients with the degree of microcracking in the cement specimens used in the half-cell experiments. The porosity of the concrete will be measured using mercury porosimetry. Details regarding the preparation of the concrete-soil half-cells and characteristics of the half-cells are presented below.

\subsection{Specified Concrete Composition for Encasement}

The concrete composition for the burial encasement was specified in Specification for Concrete Encasement for Contact-Handled Category 3 Waste. ${ }^{1}$ This specification was used as the basis for preparing a concrete for fabrication of test specimens. The specified composition includes sulfateresistant Portland Type I or Type II cement, a pozzolanic material (Class F fly ash), fine and coarse aggregates, and steel fiber. Additional specifications include a water-to-cement ratio of 0.4 and an air content $6.0 \pm 1.5 \%$. The nominal proportions and material specifications based on this initial design are listed in Table 3.1

Table 3.1. Material Specifications and Composition

\begin{tabular}{lllc}
\hline & & \multicolumn{2}{c}{ Normalized } \\
\multicolumn{1}{c}{ Material } & \multicolumn{1}{c}{ Specifications } & \multicolumn{1}{c}{$\begin{array}{c}\text { Specified Field } \\
\text { Mix }\end{array}$} & $\begin{array}{c}\text { Specification } \\
\text { Design }\end{array}$ \\
\hline Cement & Portland Type I or Type I/II sulfate-resistant cement & $381 \mathrm{~kg} / \mathrm{m}^{3}$ & 0.27 \\
Fly Ash & Class F fly ash; nominal 15\% of cement by volume & $54 \mathrm{~kg} / \mathrm{m}^{3}$ & 0.04 \\
Coarse Aggregate & No. 676 or equivalent (3/4” nominal size) & $55 \%$ by volume & 0.04 \\
Fine Aggregate & Sand & $45 \%$ by volume & 0.51 \\
Water & Nominal water:cement ratio: 0.4 & $399 \mathrm{~kg} / \mathrm{m}^{3}$ & 0.10 \\
Steel Fiber & Deformed Type I, nominal length $2.5-3.8 \mathrm{~cm}(1-1.5 ”)$ & $59 \mathrm{~kg} / \mathrm{m}^{3}$ & 0.04 \\
Air Content & & $6.0 \pm 1.5 \%$ & \\
\hline
\end{tabular}

${ }^{1}$ 1998, Waste Management (Unpublished) 


\subsection{Materials and Laboratory-Scale Mixture Design}

A laboratory-scale concrete mixture (Table 3.2) was prepared based on specifications shown in Table 3.1. Because of the required small dimensions of laboratory test specimens, the size of the coarse aggregate and the dimensions of the steel fiber specified in Table 3.1 were proportionately reduced. This was accomplished by decreasing the $2-\mathrm{cm}(\sim 0.75 \mathrm{in}$.) coarse aggregate size in the original specification to a particle size ranging from $2.83 \mathrm{~mm}$ to $2 \mathrm{~mm}$ in the laboratory mix. Aggregate passing a 7-mesh sieve and retained on a 10-mesh sieve met this particle size specification. The scaled-down steel fibers used in the laboratory mix consisted of iron particles. Based on these modifications, a concrete mix was prepared that consisted of Portland Cement (Type I and II, American Society for Testing and Materials C-150 compliant), Class F fly ash, scaled-down coarse aggregate, fine aggregate, iron particles, and a waterentraining agent (Polyheed 997). The water-entraining agent was included in the mix to facilitate the workability of the concrete. The volumes of the Polyheed 997 and the air-entraining agent, MB AE 90, were not included in the normalization calculations, because of their negligible contribution to the overall mix volume. The material specification and composition for the laboratory-scale concrete mixture is given in Table 3.2.

Table 3.2. Laboratory-Scale Material Specification and Composition

\begin{tabular}{|c|c|c|c|}
\hline Material & $\begin{array}{l}\text { Material Specifications for } \\
\text { Field Mix }\end{array}$ & $\begin{array}{c}\text { Normalized } \\
\text { Laboratory Design }\end{array}$ & $\begin{array}{c}\text { Material Specifications Used in } \\
\text { Revised Laboratory Mix } \\
\text { Comparison } \\
\end{array}$ \\
\hline Cement & $\begin{array}{l}\text { Portland Type I or Type I/II } \\
\text { sulfate-resistant cement }\end{array}$ & 0.27 & Portland Type I \& II \\
\hline Fly Ash & $\begin{array}{l}\text { Class F fly ash; nominal } 15 \% \text { of } \\
\text { cement by volume }\end{array}$ & 0.04 & $\begin{array}{l}\text { Class F fly ash; nominal } 20 \% \text { of } \\
\text { cement by volume }\end{array}$ \\
\hline Coarse & No. 676 or equivalent & 0.04 & Sieve size +7 to -10 \\
\hline Aggregate & (3/4-in. nominal size) & & $(2.83-2 \mathrm{~mm}$ size $)$ \\
\hline Fine Aggregate & Sand & 0.51 & Sand -10 sieve size $(<2 \mathrm{~mm})$ \\
\hline Water & Nominal water:cement ratio: 0.4 & 0.10 & Water-to-cement ratio: 0.5 \\
\hline Iron Powder & Iron particles & 0.04 & -200 mesh \\
\hline Polyheed 997 & & 0.00375 & Water-entraining agent \\
\hline Air Content & $6.0 \pm 1.5 \%$ & $6.0 \pm 1.5 \%$ & -- \\
\hline
\end{tabular}

\subsection{Concrete Mix and Specimen Preparation}

Concrete monoliths were prepared with mix components added in the following order: water, steel (if applicable), coarse aggregate, fine aggregate, fly ash, cement, Polyheed 997, and MB AE 90. The concrete was mixed at medium speed using a Hobart three-speed, bench-top mixer in a 4-L steel bowl. The concrete molds for casting specimens were fabricated from Schedule 40 polyvinyl chloride (PVC) piping material. Gaskets were glued to the bottom of the molds and leak tested before use. The PVC forms were pre-treated with form release, a liquid that allows the concrete specimen to release easily from the mold. The first treatment was applied 3 days prior and the second treatment was applied a few hours prior to adding wet concrete to the molds. The PVC molds were filled in the vertical position. After filling, the molds were lightly tapped on the laboratory bench until a significant decrease in the release of air bubbles was observed. The forms were stored in a humidity chamber for 28 days to provide moisture while the concrete set. The concrete monoliths were subsequently removed from the molds and half of 
the monoliths were carbonated by soaking the cores for 7 days in a saturated sodium-bicarbonate solution. The characteristics of the specimens used are listed in Table 3.3.

The diffusion tests are being conducted under unsaturated conditions at $4 \%, 7 \%$, and $15 \%$ (moisture content by weight). One concrete core of each composition was encased in a Schedule 40, 24-cm-long PVC pipe. The volume of each pipe was filled with Hanford Site sediment at the respective moisture content that was spiked with I and Tc to attain a measurable diffusion profile into the concrete half-cell. The ends of each pipe were machined and fit with o-ring gaskets to ensure that the test cells were sealed. The diffusion tests will be allowed to set horizontally and undisturbed for the test duration, 1 or 2 years, with periodic rotation of the cell by 90 degrees.

Table 3.3. Characteristics of Concrete Specimens Used in Concrete-Soil Half-Cells

\begin{tabular}{|c|c|c|c|c|c|c|c|c|c|c|}
\hline Core ID & $\begin{array}{l}\text { Length } \\
(\mathrm{cm})\end{array}$ & $\begin{array}{c}\text { Diameter } \\
(\mathrm{cm})\end{array}$ & $r^{2}$ & $\begin{array}{l}\text { Surfac } \\
\text { e Area } \\
\left(\mathrm{cm}^{2}\right)\end{array}$ & $\begin{array}{l}\text { Volum } \\
\mathrm{e}\left(\mathrm{cm}^{3}\right) \\
\end{array}$ & $\begin{array}{c}\text { Weight } \\
(\mathrm{g})\end{array}$ & $\begin{array}{l}\text { Density } \\
\left(\mathrm{g} / \mathrm{cm}^{3}\right)\end{array}$ & $\begin{array}{l}\text { Collodial } \\
\text { Iron }(\%)\end{array}$ & Carbonated & Moisture \\
\hline \multicolumn{11}{|c|}{ One-Year Diffusion Tests } \\
\hline C-08-3-0-325 & 4.09 & 4.33 & 4.68 & 84.97 & 60.10 & 131.44 & 2.19 & 0 & $\mathrm{~N}$ & 4 \\
\hline C-08-3-0-329 & 4.32 & 4.33 & 4.68 & 88.13 & 63.53 & 139.50 & 2.20 & 0 & $\mathrm{~N}$ & 7 \\
\hline C-08-3-0-330 & 3.85 & 4.33 & 4.68 & 81.77 & 56.65 & 123.50 & 2.18 & 0 & $\mathrm{~N}$ & 15 \\
\hline C-08-3-0-332 & 4.33 & 4.32 & 4.67 & 88.09 & 63.48 & 139.65 & 2.20 & 0 & Y & 4 \\
\hline C-08-3-0-333 & 4.35 & 4.33 & 4.68 & 88.57 & 64.00 & 140.79 & 2.20 & 0 & Y & 7 \\
\hline C-08-3-0-334 & 4.07 & 4.32 & 4.67 & 84.56 & 59.67 & 130.55 & 2.19 & 0 & Y & 15 \\
\hline C-08-3-4-350 & 3.84 & 4.32 & 4.67 & 81.43 & 56.28 & 127.25 & 2.26 & 4 & $\mathrm{~N}$ & 4 \\
\hline C-08-3-4-351 & 4.00 & 4.33 & 4.69 & 83.92 & 58.96 & 132.78 & 2.25 & 4 & $\mathrm{~N}$ & 7 \\
\hline C-08-3-4-353 & 4.01 & 4.33 & 4.68 & 83.99 & 59.04 & 133.38 & 2.26 & 4 & $\mathrm{~N}$ & 15 \\
\hline C-08-3-4-357 & 3.90 & 4.32 & 4.66 & 82.19 & 57.11 & 128.77 & 2.25 & 4 & Y & 4 \\
\hline C-08-3-4-359 & 3.83 & 4.32 & 4.67 & 81.25 & 56.09 & 126.50 & 2.26 & 4 & $\mathrm{Y}$ & 7 \\
\hline C-08-3-4-360 & 4.11 & 4.33 & 4.69 & 85.47 & 60.64 & 136.11 & 2.24 & 4 & Y & 15 \\
\hline C-08-3-8-401 & 4.07 & 4.32 & 4.66 & 84.40 & 59.50 & 135.91 & 2.28 & 8 & $\mathrm{~N}$ & 4 \\
\hline C-08-3-8-402 & 3.81 & 4.32 & 4.67 & 81.02 & 55.84 & 127.31 & 2.28 & 8 & $\mathrm{~N}$ & 7 \\
\hline C-08-3-8-403 & 4.00 & 4.33 & 4.69 & 83.87 & 58.91 & 133.35 & 2.26 & 8 & $\mathrm{~N}$ & 15 \\
\hline C-08-3-8-404 & 4.05 & 4.33 & 4.69 & 84.61 & 59.71 & 133.69 & 2.24 & 8 & Y & 4 \\
\hline C-08-3-8-405 & 3.86 & 4.33 & 4.68 & 81.77 & 56.65 & 126.96 & 2.24 & 8 & $\mathrm{Y}$ & 7 \\
\hline C-08-3-8-406 & 3.94 & 4.33 & 4.69 & 83.08 & 58.05 & 130.61 & 2.25 & 8 & Y & 15 \\
\hline C- $08-3-12-425$ & 4.33 & 4.27 & 4.68 & 87.54 & 62.88 & 143.44 & 2.28 & 12 & $\mathrm{~N}$ & 4 \\
\hline C-08-3-12-426 & 4.33 & 4.33 & 4.69 & 88.35 & 63.76 & 145.77 & 2.29 & 12 & $\mathrm{~N}$ & 7 \\
\hline C-08-3-12-427 & 4.33 & 4.22 & 4.70 & 86.94 & 62.23 & 141.71 & 2.28 & 12 & $\mathrm{~N}$ & 15 \\
\hline C-08-3-12-432 & 4.02 & 4.32 & 4.67 & 83.83 & 58.88 & 134.09 & 2.28 & 12 & Y & 4 \\
\hline C-08-3-12-433 & 4.15 & 4.33 & 4.68 & 85.81 & 61.01 & 139.80 & 2.29 & 12 & Y & 7 \\
\hline C- $08-3-12-435$ & 3.88 & 4.33 & 4.69 & 82.22 & 57.12 & 130.04 & 2.28 & 12 & Y & 15 \\
\hline
\end{tabular}


Table 3.3. (contd)

\begin{tabular}{|c|c|c|c|c|c|c|c|c|c|c|c|}
\hline Core ID & $\begin{array}{c}\text { Length } \\
\text { (cm) }\end{array}$ & $\begin{array}{l}\text { Diameter } \\
(\mathrm{cm})\end{array}$ & $r^{2}$ & $\begin{array}{c}\text { Surfac } \\
\text { e Area } \\
\left(\mathrm{cm}^{2}\right)\end{array}$ & $\begin{array}{l}\text { Volum } \\
\mathrm{e}\left(\mathrm{cm}^{3}\right)\end{array}$ & $\begin{array}{l}\text { Weight } \\
\text { (g) }\end{array}$ & $\begin{array}{l}\text { Density } \\
\left(\mathrm{g} / \mathrm{cm}^{3}\right)\end{array}$ & $\begin{array}{l}\text { Collodial } \\
\text { Iron (\%) }\end{array}$ & \multicolumn{2}{|l|}{ Carbonated } & \multirow[t]{2}{*}{ Moisture } \\
\hline \multicolumn{11}{|c|}{ Two-Year Diffusion Tests } & \\
\hline C-08-3-0-326 & & 4.15 & 4.34 & 4.70 & 86.13 & 61.35 & 136.30 & 2.22 & 0 & $\mathrm{~N}$ & 4 \\
\hline C-08-3-0-327 & & 4.02 & 4.32 & 4.67 & 84.01 & 59.06 & 131.30 & 2.22 & 0 & $\mathrm{~N}$ & 7 \\
\hline C-08-3-0-328 & & 4.11 & 4.33 & 4.68 & 85.24 & 60.39 & 134.10 & 2.22 & 0 & $\mathrm{~N}$ & 15 \\
\hline C-08-3-0-325 & & 4.09 & 4.33 & 4.68 & 84.97 & 60.10 & 131.44 & 2.19 & 0 & $\mathrm{Y}$ & 4 \\
\hline C-08-3-0-337 & & 4.20 & 4.32 & 4.66 & 86.28 & 61.52 & 135.86 & 2.21 & 0 & $\mathrm{Y}$ & 7 \\
\hline C-08-3-0-338 & & 4.19 & 4.33 & 4.69 & 86.54 & 61.80 & 135.91 & 2.20 & 0 & $\mathrm{Y}$ & 15 \\
\hline C-08-3-4-352 & & 4.14 & 4.32 & 4.67 & 85.56 & 60.74 & 136.22 & 2.24 & 4 & $\mathrm{~N}$ & 4 \\
\hline C-08-3-4-354 & & 4.08 & 4.33 & 4.69 & 84.99 & 60.12 & 134.63 & 2.24 & 4 & $\mathrm{~N}$ & 7 \\
\hline C-08-3-4-355 & & 4.06 & 4.33 & 4.68 & 84.60 & 59.70 & 134.13 & 2.25 & 4 & $\mathrm{~N}$ & 15 \\
\hline C-08-3-4-361 & & 3.91 & 4.33 & 4.68 & 82.48 & 57.41 & 131.18 & 2.28 & 4 & $\mathrm{Y}$ & 4 \\
\hline C-08-3-4-362 & & 4.11 & 4.32 & 4.67 & 85.12 & 60.27 & 135.96 & 2.26 & 4 & $\mathrm{Y}$ & 7 \\
\hline C-08-3-4-363 & & 4.09 & 4.32 & 4.66 & 84.70 & 59.82 & 135.08 & 2.26 & 4 & $\mathrm{Y}$ & 15 \\
\hline C-08-3-8-404 & & 4.05 & 4.33 & 4.69 & 84.61 & 59.71 & 133.69 & 2.24 & 8 & $\mathrm{~N}$ & 4 \\
\hline C-08-3-8-405 & & 3.86 & 4.33 & 4.68 & 81.77 & 56.65 & 126.96 & 2.24 & 8 & $\mathrm{~N}$ & 7 \\
\hline C-08-3-8-406 & & 3.94 & 4.33 & 4.69 & 83.08 & 58.05 & 130.61 & 2.25 & 8 & $\mathrm{~N}$ & 15 \\
\hline C-08-3-8-408 & & 4.49 & 4.33 & 4.70 & 90.60 & 66.19 & 148.87 & 2.25 & 8 & $\mathrm{Y}$ & 4 \\
\hline C-08-3-8-411 & & 4.26 & 4.33 & 4.68 & 87.32 & 62.64 & 140.64 & 2.25 & 8 & $\mathrm{Y}$ & 7 \\
\hline C-08-3-8-412 & & 4.31 & 4.33 & 4.69 & 88.09 & 63.48 & 142.26 & 2.24 & 8 & Y & 15 \\
\hline C- $08-3-12-428$ & & 4.21 & 4.33 & 4.69 & 86.65 & 61.92 & 143.22 & 2.31 & 12 & $\mathrm{~N}$ & 4 \\
\hline C-08-3-12-429 & & 4.11 & 4.33 & 4.69 & 85.43 & 60.59 & 140.25 & 2.31 & 12 & $\mathrm{~N}$ & 7 \\
\hline C- $08-3-12-430$ & & 3.84 & 4.31 & 4.65 & 81.30 & 56.16 & 129.75 & 2.31 & 12 & $\mathrm{~N}$ & 15 \\
\hline C-08-3-12-434 & & 4.13 & 4.32 & 4.66 & 85.25 & 60.41 & 138.49 & 2.29 & 12 & Y & 4 \\
\hline C- $08-3-12-436$ & & 3.90 & 4.32 & 4.66 & 82.17 & 57.09 & 131.15 & 2.30 & 12 & $\mathrm{Y}$ & 7 \\
\hline C-08-3-12-437 & & 4.21 & 4.32 & 4.67 & 86.57 & 61.84 & 142.39 & 2.30 & 12 & $\mathrm{Y}$ & 15 \\
\hline
\end{tabular}

In FYs 2009 and 2010, the soil and concrete half-cells will be sectioned and subjected to 1:1 water extractions to measure the concentration of I and Tc using ICP-MS and inductively coupled plasmaoptical emission spectrometry (ICP-OES) in soil and concrete thin slices. From the concentration data, probit plots will be constructed and the diffusion coefficients for these contaminants determined. We will correlate the calculated diffusion coefficients with the degree of microcracking in the cement specimens used in the half-cell experiments. The porosity of the concrete will be measured using mercury porosimetry. 


\subsection{Concrete-Soil Half-Cell Experiments to Determine the Diffusion of lodine and Rhenium into Fractured Concrete}

A set of diffusion experiments were initiated during FY 2007 using fractured concrete-soil half-cells. Experimental conditions in these tests are similar to the concrete-soil and soil-soil half-cell experiments conducted previously (FY 1998-2005). As previously discussed, the concrete composition for burial encasement specified in Specification for Concrete Encasement for Contact-Handled Category 3 Waste ${ }^{1}$ was used as the basis for preparing a concrete for fabrication of test specimens (Table 3.1 and Table 3.2).

Concrete monoliths were prepared with mix components added in the following order: water, steel (if applicable), coarse aggregate, fine aggregate, fly ash, cement, Polyheed 997, and MB AE 90. Soil halfcell specimens were spiked with I and Re to achieve a measurable diffusion profile in the concrete part of the half-cell. The concrete was mixed at medium speed using a Hobart three-speed, bench-top mixer in a 4-L steel bowl. The concrete molds for casting specimens were fabricated from Schedule 40 PVC piping material. Gaskets were glued to the bottom of the molds and leak tested before use. The PVC forms were pre-treated with form release, a liquid that allows the concrete specimen to release easily from the mold. The first treatment was applied 3 days prior and the second treatment was applied a few hours prior to adding wet concrete to the molds. The PVC molds were filled in the vertical position. After filling, the molds were lightly tapped on the laboratory bench until a significant decrease in the release of air bubbles was observed. The forms were stored in a humidity chamber for 28 days to provide moisture while the concrete set. The concrete monoliths were subsequently removed from the molds and half of the monoliths were carbonated by soaking the cores for 7 days in a saturated sodium-bicarbonate solution. The characteristics of the specimens used are listed in Table 4.1. In order to fracture the core, but prevent the formation of rubble, the cores were shrink-wrapped and struck with a hammer. Each core possessed a single fracture extending the length of the core, perpendicular to the concrete-soil interface.

Table 4.1. Characteristics of Cement Specimens Used in Fractured Concrete-Soil Half-Cell Tests

\begin{tabular}{|c|c|c|c|c|c|c|c|c|c|}
\hline \multirow{2}{*}{$\begin{array}{c}\text { Specimen } \\
\text { No. }\end{array}$} & \multirow{2}{*}{$\begin{array}{l}\text { Length } \\
(\mathrm{cm})\end{array}$} & \multirow{2}{*}{$\begin{array}{l}\text { Diameter } \\
(\mathrm{cm})\end{array}$} & \multirow{2}{*}{$\begin{array}{c}\text { Surface } \\
\text { Area } \\
\left(\mathrm{cm}^{2}\right)\end{array}$} & \multirow{2}{*}{$\begin{array}{l}\text { Volume } \\
\left(\mathrm{cm}^{3}\right)\end{array}$} & \multicolumn{3}{|c|}{$\begin{array}{l}\text { Moisture } \\
\text { Content }\end{array}$} & \multicolumn{2}{|c|}{ Treatment } \\
\hline & & & & & $4 \%$ & $8 \%$ & $12 \%$ & Iron & Carbonation \\
\hline C-5-0-2 & 4.15 & 4.33 & 85.89 & 61.10 & $\mathrm{x}$ & & & No & No \\
\hline C-5-4-26 & 3.89 & 4.34 & 82.44 & 57.35 & $\mathrm{x}$ & & & Yes & No \\
\hline C-5-0-1 & 4.15 & 4.33 & 86.04 & 61.25 & $\mathrm{x}$ & & & No & Yes \\
\hline C-5-4-21 & 4.02 & 4.33 & 84.04 & 59.10 & $\mathrm{x}$ & & & Yes & Yes \\
\hline C-5-0-7 & 4.24 & 4.33 & 87.02 & 62.32 & & $\mathrm{x}$ & & No & No \\
\hline C-5-4-27 & 3.98 & 4.34 & 83.75 & 58.77 & & $\mathrm{x}$ & & Yes & No \\
\hline$C-5-0-5$ & 4.18 & 4.34 & 86.63 & 61.89 & & $\mathrm{x}$ & & No & Yes \\
\hline C-5-4-23 & 4.12 & 4.34 & 85.68 & 60.87 & & $\mathrm{x}$ & & Yes & Yes \\
\hline C-5-0-10 & 4.37 & 4.34 & 89.05 & 64.51 & & & $\mathrm{x}$ & No & No \\
\hline C-5-4-30 & 3.95 & 4.34 & 83.31 & 58.29 & & & $\mathrm{x}$ & Yes & No \\
\hline C-5-0-6 & 4.76 & 4.34 & 94.54 & 70.48 & & & $\mathrm{x}$ & No & Yes \\
\hline C-5-4-24 & 4.52 & 4.34 & 91.26 & 66.91 & & & $\mathrm{x}$ & Yes & Yes \\
\hline
\end{tabular}

The diffusion tests were conducted under unsaturated conditions at $4 \%, 7 \%$, and $15 \%$ (moisture content by weight). One concrete core of each composition was encased in a Schedule 40, 24-cm-long

${ }^{1}$ 1998, Waste Management (Unpublished) 
PVC pipe. The volume of each pipe was filled with Hanford Site sediment at the respective moisture content that was spiked with I and Re to attain a measurable diffusion profile into the fractured concrete. The ends of each pipe were machined and fit with o-ring gaskets to ensure that the test cells were sealed. The diffusion tests were allowed to set horizontally and undisturbed for a period of 1 year with periodic rotation of the cell by 90 degrees. At the conclusion of the test period in FY 2008, the end caps of the cells were removed and the sediment was extruded at approximately $1-\mathrm{cm}$ intervals along the length of the half-cell (Figure 4.1). Concrete half-cells were thin-sliced using a Buehler slow-speed saw fitted with a diamond blade. Cutting was done without water cooling to prevent the leaching of soluble I and Re during the cutting process. One half of the concrete half-cell was sliced parallel to the concrete-soil interface. The other half of the concrete half-cell was sliced parallel to the fracture (perpendicular to the concrete-soil interface). The concrete slices were then ground using an agate mortar and pestle. The soil and concrete half-cells were sectioned and subjected to 1:1 deionized water extractions. The concentrations of I and Re we measured using ICP-MS and ICP-OES, respectively, in soil and concrete thin slices.
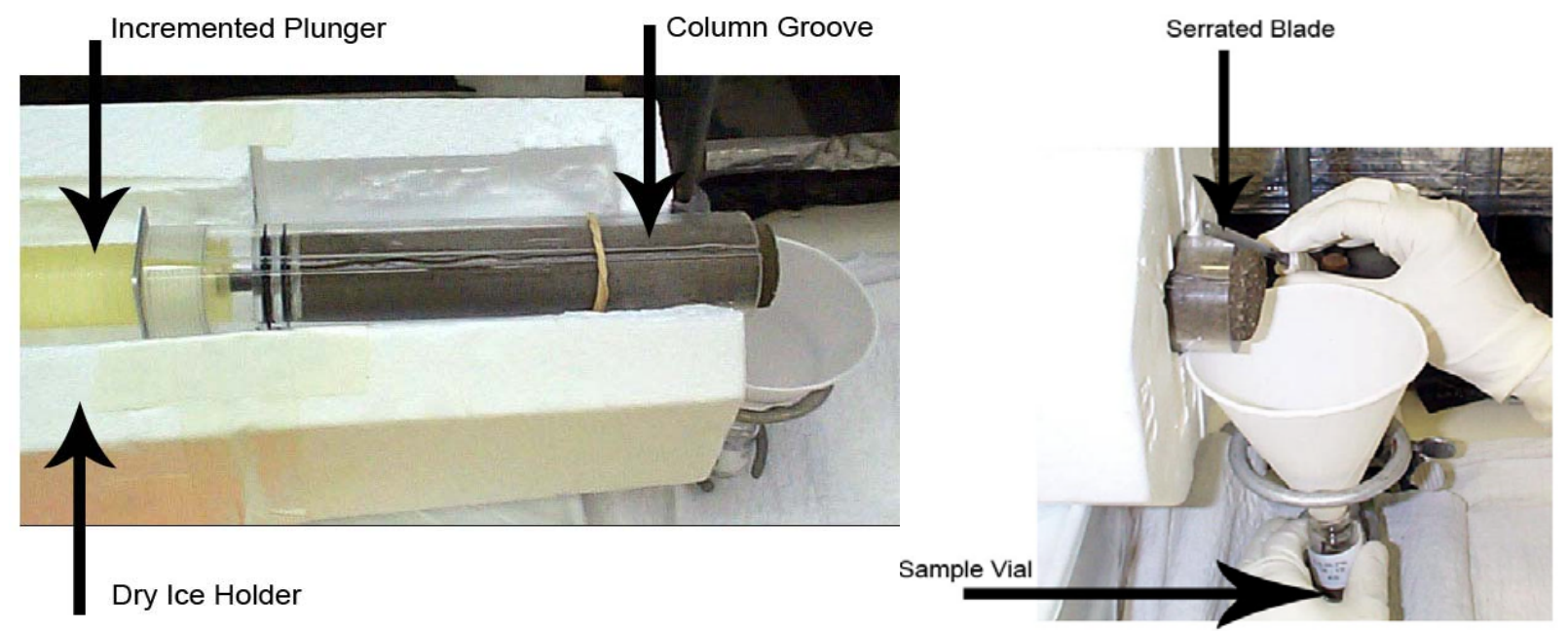

Figure 4.1. a) Mechanism for Soil Sampling from a Concrete-Soil Diffusion Half-Cell, b) Soil Sampling from a Diffusion Half-Cell.

\subsection{Concentration Profile Results and Discussion}

The concentration profiles for I and Re in the soil half-cell are presented in Figure 4.2. The concentration of I and Re in the sediment half-cells displays a uniform distribution throughout the length of the half-cells irrespective of moisture content. The concentration of I contained in the sediment halfcells was generally less than the concentration of Re (Figure 4.2 and Table 4.2). 

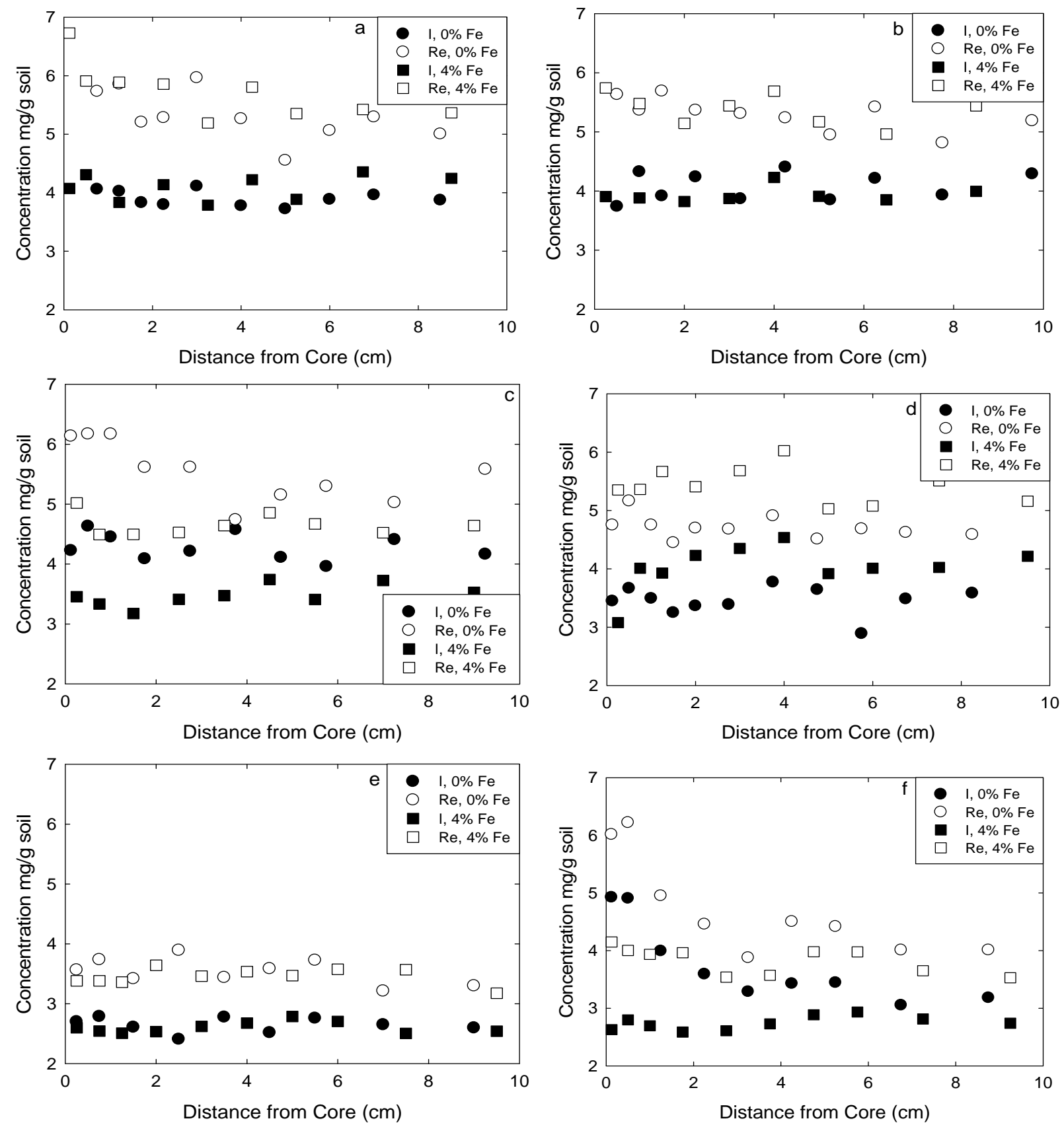

Figure 4.2. Concentration Profiles for Soil Half-Cell I and Re Profiles. a) 4\% with non-carbonated concrete monoliths, b) $4 \%$ with carbonated concrete monoliths, c) $7 \%$ with non-carbonated concrete monoliths, d) $7 \%$ with carbonated concrete monoliths, e) $15 \%$ with non-carbonated concrete monoliths, and f) $15 \%$ with carbonated concrete monoliths. 
Table 4.2. Concentration of Iodine and Rhenium (mg/g) for Soil Half-Cell Profiles at 4\%, 7\%, and 15\% Moisture Content

\begin{tabular}{|c|c|c|c|c|c|c|c|c|c|c|c|}
\hline $\begin{array}{c}\text { Distance } \\
\text { From } \\
\text { Core, } \mathrm{mm} \\
\end{array}$ & $\begin{array}{c}\mathrm{I}, \\
\mathrm{mg} / \mathrm{g}\end{array}$ & $\begin{array}{c}\mathrm{Re}, \\
\mathrm{mg} / \mathrm{g}\end{array}$ & $\begin{array}{c}\text { Distance } \\
\text { From } \\
\text { Core, } \mathrm{mm} \\
\end{array}$ & $\begin{array}{c}\mathrm{I}, \\
\mathrm{mg} / \mathrm{g}\end{array}$ & $\begin{array}{c}\mathrm{Re}, \\
\mathrm{mg} / \mathrm{g}\end{array}$ & $\begin{array}{c}\text { Distance } \\
\text { From } \\
\text { Core, } \\
\mathrm{mm} \\
\end{array}$ & $\begin{array}{c}\mathrm{I}, \\
\mathrm{mg} / \mathrm{g}\end{array}$ & $\begin{array}{c}\mathrm{Re}, \\
\mathrm{mg} / \mathrm{g}\end{array}$ & $\begin{array}{c}\text { Distance } \\
\text { From } \\
\text { Core, } \\
\mathrm{mm} \\
\end{array}$ & $\begin{array}{c}\mathrm{I}, \\
\mathrm{mg} / \mathrm{g}\end{array}$ & $\begin{array}{c}\mathrm{Re}, \\
\mathrm{mg} / \mathrm{g}\end{array}$ \\
\hline \multicolumn{3}{|c|}{$4 \%$ Soil--NC 0\% Iron } & \multicolumn{3}{|c|}{$4 \%$ Soil--NC 4\% Iron } & \multicolumn{3}{|c|}{$4 \%$ Soil--C $0 \%$ Iron } & \multicolumn{3}{|c|}{$4 \%$ Soil--C-4\% Iron } \\
\hline 10.5 & 4.0 & 5.1 & 8.75 & 4.2 & 5.4 & 9.75 & 4.3 & 5.2 & 8.5 & 4.0 & 5.4 \\
\hline 8.5 & 3.9 & 5.0 & 6.75 & 4.4 & 5.4 & 7.75 & 3.9 & 4.8 & 6.5 & 3.9 & 5.0 \\
\hline 7 & 4.0 & 5.3 & 5.25 & 3.9 & 5.4 & 6.25 & 4.2 & 5.4 & 5 & 3.9 & 5.2 \\
\hline 6 & 3.9 & 5.1 & 4.25 & 4.2 & 5.8 & 5.25 & 3.8 & 4.9 & 4 & 4.2 & 5.7 \\
\hline 5 & 3.7 & 4.6 & 3.25 & 3.8 & 5.2 & 4.25 & 4.4 & 5.2 & 3 & 3.9 & 5.4 \\
\hline 4 & 3.8 & 5.3 & 2.25 & 4.1 & 5.9 & 3.25 & 3.9 & 5.3 & 2 & 3.8 & 5.1 \\
\hline 3 & 4.1 & 6.0 & 1.25 & 3.8 & 5.9 & 2.25 & 4.2 & 5.4 & 1 & 3.9 & 5.5 \\
\hline 2.25 & 3.8 & 5.3 & 0.5 & 4.3 & 5.9 & 1.5 & 3.9 & 5.7 & 0.25 & 3.9 & 5.7 \\
\hline 1.75 & 3.8 & 5.2 & 0.125 & 4.1 & 6.7 & 1 & 4.3 & 5.4 & & & \\
\hline 1.25 & 4.0 & 5.9 & & & & 0.5 & 3.7 & 5.6 & & & \\
\hline 0.75 & 4.1 & 5.7 & & & & 0.125 & 3.7 & 5.9 & & & \\
\hline 0.25 & 4.4 & 5.5 & & & & & & & & & \\
\hline \multicolumn{3}{|c|}{ 7\% Soil--NC 0\% Iron } & \multicolumn{3}{|c|}{ 7\% Soil--NC 4\% Iron } & \multicolumn{3}{|c|}{ 7\% Soil--C 0\% Iron } & \multicolumn{3}{|c|}{ 7\% Soil--C-4\% Iron } \\
\hline 9.25 & 4.2 & 5.6 & 9 & 3.5 & 4.6 & 10.25 & 3.5 & 4.4 & 9.5 & 4.2 & 5.2 \\
\hline 7.25 & 4.4 & 5.0 & 7 & 3.7 & 4.5 & 8.25 & 3.6 & 4.6 & 7.5 & 4.0 & 5.5 \\
\hline 5.75 & 4.0 & 5.3 & 5.5 & 3.4 & 4.7 & 6.75 & 3.5 & 4.6 & 6 & 4.0 & 5.1 \\
\hline 4.75 & 4.1 & 5.2 & 4.5 & 3.7 & 4.9 & 5.75 & 2.9 & 4.7 & 5 & 3.9 & 5.0 \\
\hline 3.75 & 4.6 & 4.7 & 3.5 & 3.5 & 4.6 & 4.75 & 3.6 & 4.5 & 4 & 4.5 & 6.0 \\
\hline 2.75 & 4.2 & 5.6 & 2.5 & 3.4 & 4.5 & 3.75 & 3.8 & 4.9 & 3 & 4.3 & 5.7 \\
\hline 1.75 & 4.1 & 5.6 & 1.5 & 3.2 & 4.5 & 2.75 & 3.4 & 4.7 & 2 & 4.2 & 5.4 \\
\hline 1 & 4.5 & 6.2 & 0.75 & 3.3 & 4.5 & 2 & 3.4 & 4.7 & 1.25 & 3.9 & 5.7 \\
\hline 0.5 & 4.6 & 6.2 & 0.25 & 3.5 & 5.0 & 1.5 & 3.2 & 4.4 & 0.75 & 4.0 & 5.4 \\
\hline \multirow[t]{3}{*}{0.125} & 4.2 & 6.1 & & & & 1 & 3.5 & 4.7 & 0.25 & 3.1 & 5.4 \\
\hline & & & & & & 0.5 & 3.7 & 5.2 & & & \\
\hline & & & & & & 0.125 & 3.4 & 4.7 & & & \\
\hline \multicolumn{3}{|c|}{$15 \%$ Soil--NC $0 \%$ Iron } & \multicolumn{3}{|c|}{$15 \%$ Soil--NC 4\% Iron } & \multicolumn{3}{|c|}{$15 \%$ Soil--C $0 \%$ Iron } & \multicolumn{3}{|c|}{$15 \%$ Soil--C-4\% Iron } \\
\hline 9 & 2.6 & 3.3 & 9.5 & 2.5 & 3.2 & 8.75 & 3.2 & 4.0 & 9.25 & 2.7 & 3.5 \\
\hline 7 & 2.6 & 3.2 & 7.5 & 2.5 & 3.6 & 6.75 & 3.1 & 4.0 & 7.25 & 2.8 & 3.7 \\
\hline 5.5 & 2.8 & 3.7 & 6 & 2.7 & 3.6 & 5.25 & 3.4 & 4.4 & 5.75 & 2.9 & 4.0 \\
\hline 4.5 & 2.5 & 3.6 & 5 & 2.8 & 3.5 & 4.25 & 3.4 & 4.5 & 4.75 & 2.9 & 4.0 \\
\hline 3.5 & 2.8 & 3.4 & 4 & 2.7 & 3.5 & 3.25 & 3.3 & 3.9 & 3.75 & 2.7 & 3.6 \\
\hline 2.5 & 2.4 & 3.9 & 3 & 2.6 & 3.5 & 2.25 & 3.6 & 4.5 & 2.75 & 2.6 & 3.5 \\
\hline 1.5 & 2.6 & 3.4 & 2 & 2.5 & 3.6 & 1.25 & 4.0 & 5.0 & 1.75 & 2.6 & 4.0 \\
\hline 0.75 & 2.8 & 3.7 & 1.25 & 2.5 & 3.4 & 0.5 & 4.9 & 6.2 & 1 & 2.7 & 3.9 \\
\hline \multirow[t]{2}{*}{0.25} & 2.7 & 3.6 & 0.75 & 2.5 & 3.4 & 0.125 & 4.9 & 6.0 & 0.5 & 2.8 & 4.0 \\
\hline & & & 0.25 & 2.6 & 3.4 & & & & 0.125 & 2.6 & 4.2 \\
\hline
\end{tabular}

The fracture within the concrete half-cell presents a possible unobstructed path for contaminant migration. Therefore, it was postulated that I and Re may migrate through the fracture and then into the concrete monolith at the fracture face, in addition to the concrete-soil interface. One half of the concrete monolith was sectioned parallel to the concrete-soil interface; the second half was sectioned parallel to the fracture (perpendicular to the concrete-soil interface). Figure 4.3 and Table 4.3 present the mass of I and Re per mass of concrete for the concrete monolith half that was sectioned parallel to the concrete-soil interface. The concentrations of I and Re quantified within the monoliths at $7 \%$ and $15 \%$ moisture contents, which were not carbonated, were lower at the interface than that measured at $4 \%$ moisture content. At 4\% moisture content, the concentration of I and Re were greatest within the first $5 \mathrm{~mm}$ and 

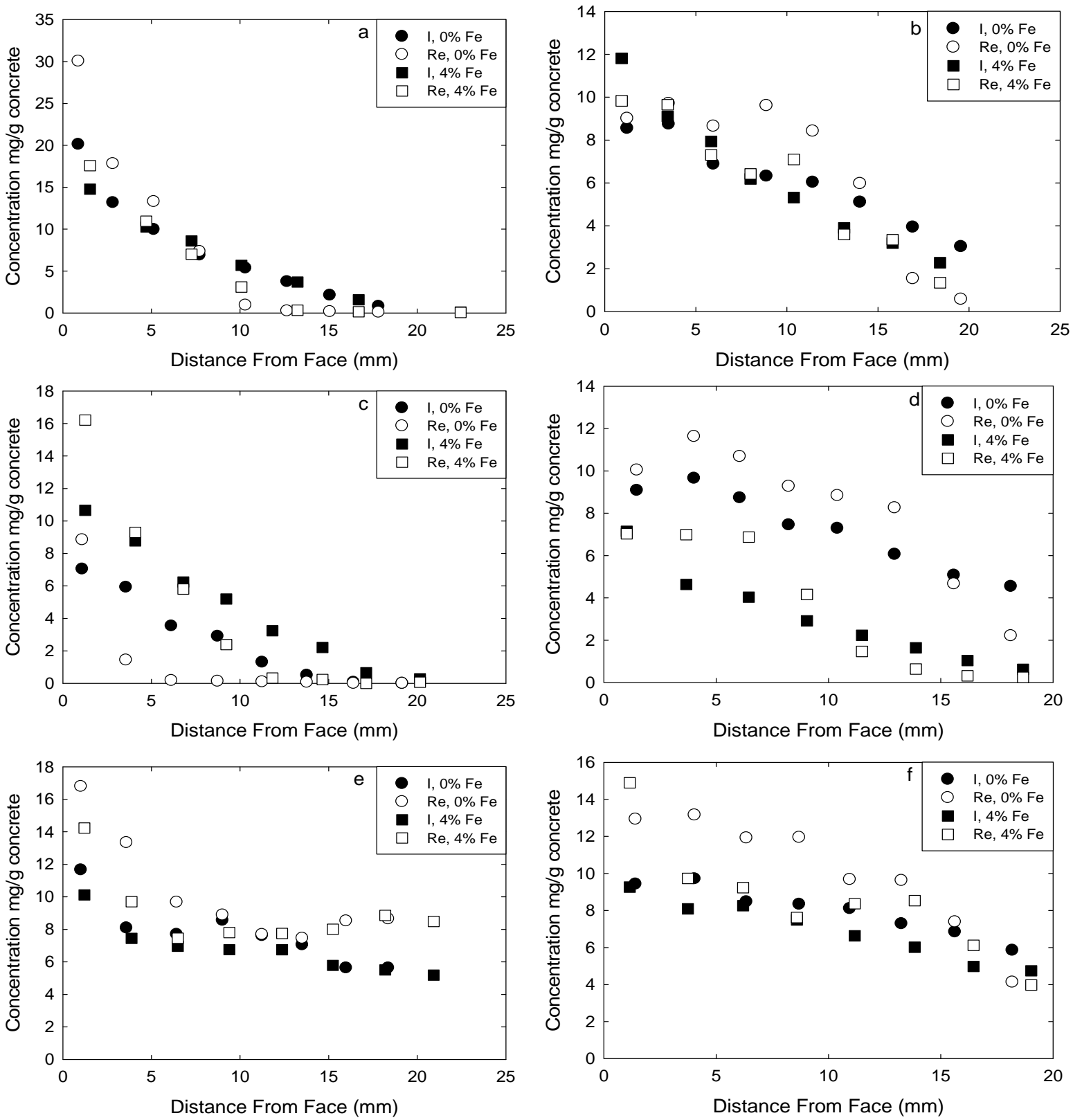

Figure 4.3. I and Re Concentration Profiles. a) 4\%, non-carbonated concrete monoliths, b) 4\%, carbonated concrete monoliths, c) 7\%, non-carbonated concrete monoliths, d) 7\%, carbonated concrete monoliths, e) $15 \%$, non-carbonated concrete monoliths, and f) $15 \%$, carbonated concrete monoliths sectioned parallel to the concrete-soil interface. 
Table 4.3. Concentration of Iodine and Rhenium $(\mathrm{mg} / \mathrm{g}$ ) for Concrete Half-Cell Profiles at 4\%, 7\%, and 15\% Moisture Content Sectioned Parallel to the Concrete-Soil Interface

\begin{tabular}{|c|c|c|c|c|c|c|c|c|c|c|c|}
\hline $\begin{array}{l}\text { Distance } \\
\text { From } \\
\text { Interface, } \\
\mathrm{mm} \\
\end{array}$ & $\begin{array}{c}\mathrm{I}, \\
\mathrm{mg} / \mathrm{g}\end{array}$ & $\begin{array}{c}\mathrm{Re}, \\
\mathrm{mg} / \mathrm{g}\end{array}$ & $\begin{array}{l}\text { Distance } \\
\text { From } \\
\text { Interface, } \\
\text { mm }\end{array}$ & $\begin{array}{c}\mathrm{I}, \\
\mathrm{mg} / \mathrm{g}\end{array}$ & $\begin{array}{c}\mathrm{Re}, \\
\mathrm{mg} / \mathrm{g}\end{array}$ & $\begin{array}{c}\text { Distance } \\
\text { From } \\
\text { Interface, } \\
\text { mm }\end{array}$ & $\begin{array}{c}\mathrm{I}, \\
\mathrm{mg} / \mathrm{g}\end{array}$ & $\begin{array}{l}\mathrm{Re}, \\
\mathrm{mg} / \mathrm{g}\end{array}$ & $\begin{array}{c}\text { Distance } \\
\text { From } \\
\text { Interface, } \\
\text { mm }\end{array}$ & $\begin{array}{c}\mathrm{I}, \\
\mathrm{mg} / \mathrm{g}\end{array}$ & $\begin{array}{r}\mathrm{Re}, \\
\mathrm{mg} / \mathrm{g}\end{array}$ \\
\hline \multicolumn{3}{|c|}{ 4\% Soil--NC 0\% Iron } & \multicolumn{3}{|c|}{$4 \%$ Soil--NC 4\% Iron } & \multicolumn{3}{|c|}{$4 \%$ Soil--C $0 \%$ Iron } & \multicolumn{3}{|c|}{$4 \%$ Soil--C-4\% Iron } \\
\hline 0.9 & 20.11 & 30.05 & 1.5 & 14.76 & 17.57 & 1.2 & 8.55 & 9.01 & 0.9 & 11.81 & 9.83 \\
\hline 2.8 & 13.17 & 17.80 & 4.7 & 10.26 & 10.96 & 3.5 & 8.74 & 9.70 & 3.5 & 9.10 & 9.64 \\
\hline 5.1 & 9.95 & 13.29 & 7.3 & 8.58 & 7.01 & 6.0 & 6.88 & 8.64 & 5.8 & 7.93 & 7.30 \\
\hline 7.7 & 6.90 & 7.32 & 10.1 & 5.69 & 3.09 & 8.9 & 6.32 & 9.60 & 8.0 & 6.19 & 6.42 \\
\hline 10.3 & 5.35 & 0.92 & 13.2 & 3.70 & 0.33 & 11.4 & 6.03 & 8.41 & 10.4 & 5.32 & 7.10 \\
\hline 12.7 & 3.74 & 0.24 & 16.7 & 1.57 & 0.14 & 14.0 & 5.10 & 5.97 & 13.1 & 3.90 & 3.60 \\
\hline 15.1 & 2.12 & 0.15 & 22.4 & 0.12 & 0.05 & 16.9 & 3.94 & 1.53 & 15.8 & 3.19 & 3.35 \\
\hline 17.8 & 0.80 & 0.09 & & & & 19.6 & 3.03 & 0.57 & 18.4 & 2.28 & 1.34 \\
\hline \multicolumn{3}{|c|}{$7 \%$ Soil--NC 0\% Iron } & \multicolumn{3}{|c|}{ 7\% Soil--NC 4\% Iron } & \multicolumn{3}{|c|}{$7 \%$ Soil--C $0 \%$ Iron } & \multicolumn{3}{|c|}{$7 \%$ Soil--C-4\% Iron } \\
\hline 1.1 & 7.04 & 8.84 & 1.3 & 10.66 & 16.22 & 1.5 & 9.08 & 10.04 & 1.0 & 7.15 & 7.03 \\
\hline 3.6 & 5.92 & 1.44 & 4.1 & 8.77 & 9.30 & 4.0 & 9.65 & 11.62 & 3.7 & 4.64 & 6.99 \\
\hline 6.1 & 3.54 & 0.18 & 6.8 & 6.24 & 5.81 & 6.1 & 8.73 & 10.68 & 6.5 & 4.03 & 6.88 \\
\hline 8.7 & 2.90 & 0.13 & 9.2 & 5.20 & 2.39 & 8.2 & 7.45 & 9.27 & 9.0 & 2.91 & 4.16 \\
\hline 11.3 & 1.30 & 0.09 & 11.8 & 3.24 & 0.33 & 10.4 & 7.28 & 8.83 & 11.5 & 2.24 & 1.47 \\
\hline 13.8 & 0.50 & 0.06 & 14.7 & 2.21 & 0.24 & 13.0 & 6.06 & 8.25 & 13.9 & 1.64 & 0.64 \\
\hline 16.4 & 0.07 & 0.00 & 17.1 & 0.66 & 0.00 & 15.6 & 5.08 & 4.66 & 16.2 & 1.04 & 0.32 \\
\hline 19.2 & 0.00 & 0.00 & 20.2 & 0.28 & 0.07 & 18.1 & 4.54 & 2.20 & 18.7 & 0.62 & 0.24 \\
\hline \multicolumn{3}{|c|}{$15 \%$ Soil--NC $0 \%$ Iron } & \multicolumn{3}{|c|}{$15 \%$ Soil--NC 4\% Iron } & \multicolumn{3}{|c|}{$15 \%$ Soil--C $0 \%$ Iron } & \multicolumn{3}{|c|}{$15 \%$ Soil--C-4\% Iron } \\
\hline 1.0 & 11.65 & 16.79 & 1.2 & 10.12 & 14.23 & 1.4 & 9.42 & 12.93 & 1.2 & 9.26 & 14.89 \\
\hline 3.6 & 8.09 & 13.33 & 3.9 & 7.45 & 9.70 & 4.0 & 9.71 & 13.15 & 3.7 & 8.09 & 9.73 \\
\hline 6.4 & 7.69 & 9.67 & 6.5 & 6.96 & 7.45 & 6.4 & 8.47 & 11.92 & 6.2 & 8.26 & 9.23 \\
\hline 9.0 & 8.55 & 8.88 & 9.4 & 6.75 & 7.80 & 8.7 & 8.34 & 11.94 & 8.6 & 7.49 & 7.62 \\
\hline 11.2 & 7.62 & 7.69 & 12.4 & 6.75 & 7.75 & 11.0 & 8.10 & 9.67 & 11.2 & 6.63 & 8.36 \\
\hline 13.5 & 7.05 & 7.46 & 15.2 & 5.78 & 8.01 & 13.3 & 7.29 & 9.62 & 13.8 & 6.01 & 8.53 \\
\hline 16.0 & 5.62 & 8.52 & 18.2 & 5.50 & 8.85 & 15.6 & 6.84 & 7.38 & 16.5 & 4.98 & 6.12 \\
\hline 18.4 & 5.62 & 8.64 & 20.9 & 5.18 & 8.48 & 18.2 & 5.85 & 4.12 & 19.0 & 4.74 & 3.98 \\
\hline
\end{tabular}

displayed an asymptotic decrease in concentration to $\sim 1 \mathrm{mg} / \mathrm{g}$ within $17 \mathrm{~mm}$. There was no measurable effect of iron on the interfacial concentration or diffusion of I or Re. However, the comparison of diffusion of $\mathrm{I}$ and $\mathrm{Re}$ at $7 \%$ and $15 \%$ shows a number of deviations. In the concrete monolith without iron and not carbonated, the diffusion of I and Re appears to be more rapid at $7 \%$ in the presence of iron. In the absence of iron, the interfacial concentration was $\sim 7 \mathrm{mg} / \mathrm{g}$ concrete and decreased linearly over the first $15 \mathrm{~mm}$. In the presence of iron, the interfacial concentration was $\sim 11 \mathrm{mg} / \mathrm{g}$ concrete and also displayed a linear decrease over the first $20 \mathrm{~mm}$. The interfacial concentration of Re also was greater in the presence of iron, $16 \mathrm{mg} / \mathrm{g}$ concrete, but displayed a rapid asymptotic decrease in concentration over the first $10 \mathrm{~mm}$. A similar asymptotic decrease in concentration was observed for Re in the absence of iron, with an interfacial concentration of $\sim 9 \mathrm{mg} / \mathrm{g}$ concrete. At $15 \%$ moisture content the initial concentration of I and Re range from 10 to $17 \mathrm{mg} / \mathrm{g}$, which decreases rapidly over the first $5 \mathrm{~mm}$ to a 
relative steady-state concentration of $\sim 8 \mathrm{mg} / \mathrm{g}$ that is sustained throughout the extent of the monolith. There was no measurable effect of iron on the interfacial concentration or diffusion of I or Re.

In carbonated monoliths, the interfacial concentration of I and Re at $4 \%, 7 \%$, and $15 \%$ moisture content were comparable, $\sim 10-12 \mathrm{mg} / \mathrm{g}$ concrete. The concentration of I and Re displayed a linear decrease in concentration over the length of the monolith at all moisture contents, irrespective of iron content. At 4\% moisture content, there was no measureable effect of iron on the diffusion of I or Re. The concentration decreased linearly over $20 \mathrm{~mm}$ of the concrete monolith. At 7\%, the diffusion of I and Re displayed a sustained diffusion over the first $\sim 5 \mathrm{~mm}$ of the concrete monolith followed by linear diffusion over the subsequent $15 \mathrm{~mm}$ of concrete monolith. The diffusion of I and Re were greatest in the absence of iron. The interfacial concentrations of I and Re in the absence of iron were 10 and $9 \mathrm{mg} / \mathrm{g}$ concrete, respectively. In the presence of iron the interfacial concentration was $8 \mathrm{mg} / \mathrm{g}$ concrete. At $15 \%$ moisture content, the interfacial concentrations of Re and I, respectively, were $\sim 14 \mathrm{mg} / \mathrm{g}$ concrete and $\sim 9 \mathrm{mg} / \mathrm{g}$ concrete, irrespective of iron content. For Re, in the presence of iron concentration rapidly decreased within the first $5 \mathrm{~mm}$ and exhibited a very slow decrease in concentration over the length of the monolith to a final concentration of $5 \mathrm{mg} / \mathrm{g}$ concrete. In the absence of iron, the concentration of Re was sustained at $\sim 12 \mathrm{mg} / \mathrm{g}$ concrete over the first $10 \mathrm{~mm}$ and then exhibited a slow decrease in concentration over the remaining $10 \mathrm{~mm}$ of monolith to a final concentration of $5 \mathrm{mg} / \mathrm{g}$ concrete. The inclusion of iron decreased the diffusion of Re within the first $10 \mathrm{~mm}$, but had no effect within the remaining $10 \mathrm{~mm}$ of the monolith. There was no measurable effect of iron on the diffusion of iodine. The overall diffusion of I and $\mathrm{Re}$ is greater in carbonated rather than non-carbonated concrete monoliths. This agrees with previous results (Wellman et al. 2007b; Wellman et al. 2006) which demonstrated carbonation results in the formation of microcracks within concrete monoliths which can facilitate diffusion.

The behavior of I and Re within concrete sections taken perpendicular to the concrete-soil interface (parallel to the fracture) was markedly different relative to those sectioned parallel to the concrete-soil interface. Diffusion of I and Re in the presence of iron, in non-carbonated cores was comparable at 7\% and $15 \%$ moisture content, $\sim 6-8 \mathrm{mg} / \mathrm{g}$ throughout the concrete profile. At $4 \%$ moisture content, however, the diffusion of I and Re initiated at $\sim 8 \mathrm{mg} / \mathrm{g}$ and then rapidly decreased to a sustained mass of $\sim 2 \mathrm{mg} / \mathrm{g}$ throughout the concrete profile. This accords with previous results, suggesting a direct relationship between diffusion within concrete monoliths and the degree of moisture content (Wellman et al. 2006; Mattigod et al. 2001). The behavior of I and Re in non-carbonated monoliths that do not contain iron is comparable at $4 \%$ and $15 \%$ moisture content to that observed in the presence of iron. However, at $7 \%$ moisture content the concentration of I and Re is $\sim 1 \mathrm{mg} / \mathrm{g}$ throughout the monolith profile, substantially less than the sustained concentration of $\sim 5 \mathrm{mg} / \mathrm{g}$ measured in the presence of iron. This result accords with previous findings (Wellman et al. 2007b; Wellman et al. 2006) suggesting that the inclusion of iron results in the formation of microcracks that can facilitate diffusion. However, the lack of observable effect at $4 \%$ and $15 \%$ moisture content is under further investigation. In FY 2009, the porosity of the concrete will be measured using mercury porosimetry and the degree of microcracking within the concrete monoliths will be evaluated using scanning electron microscopy. In carbonated concrete monoliths, the behavior of I and Re was comparable to that observed in non-carbonated monoliths with the noted exception at 7\% moisture content. At 7\% moisture content, the diffusion of I and Re was greater in the absence of iron than in the presence of iron. Comparable behavior was observed for the other half of this monolith that was sectioned parallel to the concrete-soil interface. 

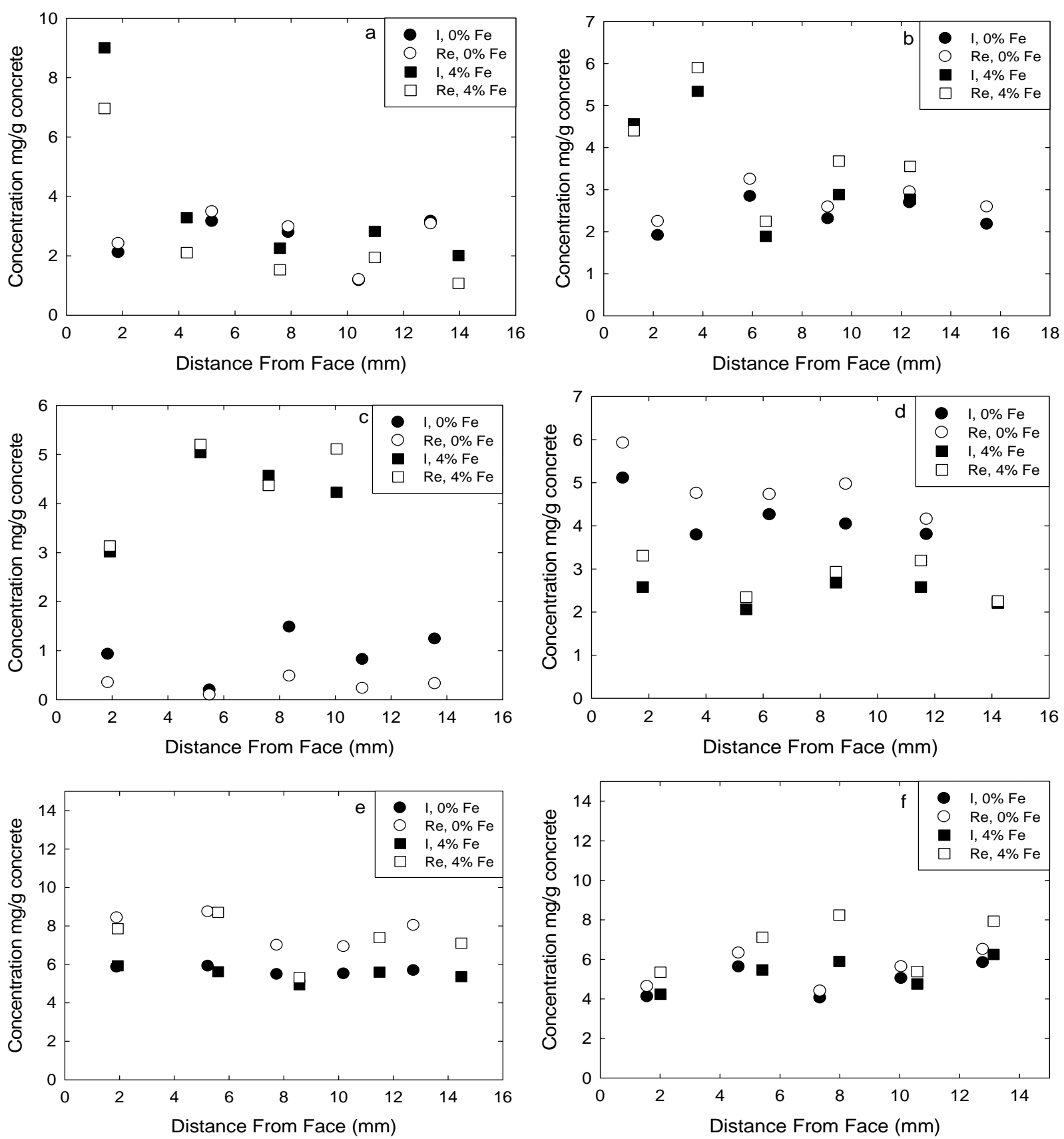

Figure 4.4. I and Re Concentration Profiles. a) 4\%, non-carbonated concrete monoliths, b) 4\%, carbonated concrete monoliths, c) $7 \%$, non-carbonated concrete monoliths, d) $7 \%$, carbonated concrete monoliths, e) $15 \%$, non-carbonated concrete monoliths, and f) $15 \%$,carbonated concrete monoliths sectioned perpendicular to the concrete-soil interface (parallel to the fracture). 
Table 4.4. Concentration of Iodine and Rhenium (mg/g) for Concrete Half-Cell Profiles at 4\%, 7\%, and 15\% Moisture Content Sectioned Perpendicular to the Concrete-Soil Interface (Parallel to the Concrete Fracture)

\begin{tabular}{|c|c|c|c|c|c|c|c|c|c|c|c|}
\hline $\begin{array}{c}\text { Distance } \\
\text { From } \\
\text { Interface, } \\
\text { mm }\end{array}$ & $\begin{array}{c}\mathrm{I}, \\
\mathrm{mg} / \mathrm{g}\end{array}$ & $\begin{array}{l}\mathrm{Re}, \\
\mathrm{mg} / \mathrm{g}\end{array}$ & $\begin{array}{c}\text { Distance } \\
\text { From } \\
\text { Interface, } \\
\text { mm }\end{array}$ & $\begin{array}{c}\mathrm{I}, \\
\mathrm{mg} / \mathrm{g}\end{array}$ & $\begin{array}{c}\mathrm{Re}, \\
\mathrm{mg} / \mathrm{g}\end{array}$ & $\begin{array}{c}\text { Distance } \\
\text { From } \\
\text { Interface, } \\
\text { mm }\end{array}$ & $\begin{array}{c}\mathrm{I}, \\
\mathrm{mg} / \mathrm{g}\end{array}$ & $\begin{array}{l}\mathrm{Re}, \\
\mathrm{mg} / \mathrm{g}\end{array}$ & $\begin{array}{c}\text { Distance } \\
\text { From } \\
\text { Interface, } \\
\text { mm }\end{array}$ & $\begin{array}{c}\mathrm{I}, \\
\mathrm{mg} / \mathrm{g}\end{array}$ & $\begin{array}{c}\mathrm{Re}, \\
\mathrm{mg} / \mathrm{g}\end{array}$ \\
\hline \multicolumn{3}{|c|}{$4 \%$ Soil--NC $0 \%$ Iron } & \multicolumn{3}{|c|}{ 4\% Soil--NC 4\% Iron } & \multicolumn{3}{|c|}{$4 \%$ Soil--C $0 \%$ Iron } & \multicolumn{3}{|c|}{ 4\% Soil--C-4\% Iron } \\
\hline 1.9 & 2.11 & 2.41 & 1.4 & 9.00 & 6.96 & 2.2 & 1.91 & 2.24 & 1.2 & 4.57 & 4.40 \\
\hline 5.2 & 3.15 & 3.48 & 4.3 & 3.28 & 2.11 & 5.9 & 2.84 & 3.24 & 3.8 & 5.34 & 5.90 \\
\hline 7.9 & 2.79 & 2.97 & 7.6 & 2.26 & 1.53 & 9.1 & 2.30 & 2.59 & 6.5 & 1.89 & 2.25 \\
\hline 10.4 & 1.16 & 1.19 & 11.0 & 2.82 & 1.95 & 12.3 & 2.69 & 2.95 & 9.5 & 2.88 & 3.68 \\
\hline 13.0 & 3.16 & 3.08 & 14.0 & 2.00 & 1.07 & 15.5 & 2.17 & 2.59 & 12.4 & 2.77 & 3.55 \\
\hline \multicolumn{3}{|c|}{ 7\% Soil--NC $0 \%$ Iron } & \multicolumn{3}{|c|}{ 7\% Soil--NC 4\% Iron } & \multicolumn{3}{|c|}{ 7\% Soil--C 0\% Iron } & \multicolumn{3}{|c|}{ 7\% Soil--C-4\% Iron } \\
\hline 1.9 & 0.93 & 0.35 & 1.9 & 3.02 & 3.13 & 1.1 & 5.10 & 5.92 & 1.8 & 2.58 & 3.31 \\
\hline 5.5 & 0.20 & 0.10 & 5.2 & 5.04 & 5.20 & 3.7 & 3.78 & 4.75 & 5.4 & 2.06 & 2.34 \\
\hline 8.4 & 1.48 & 0.48 & 7.6 & 4.57 & 4.37 & 6.2 & 4.26 & 4.72 & 8.5 & 2.68 & 2.93 \\
\hline 11.0 & 0.82 & 0.23 & 10.0 & 4.23 & 5.11 & 8.9 & 4.03 & 4.96 & 11.5 & 2.58 & 3.20 \\
\hline 13.6 & 1.23 & 0.33 & 12.6 & 5.10 & 4.90 & 11.7 & 3.80 & 4.15 & 14.2 & 2.21 & 2.25 \\
\hline \multicolumn{3}{|c|}{ 15\% Soil--NC 0\% Iron } & \multicolumn{3}{|c|}{$15 \%$ Soil--NC 4\% Iron } & \multicolumn{3}{|c|}{$15 \%$ Soil--C $0 \%$ Iron } & \multicolumn{3}{|c|}{$15 \%$ Soil--C-4\% Iron } \\
\hline 1.9 & 5.85 & 8.42 & 1.9 & 5.93 & 7.85 & 1.6 & 4.10 & 4.63 & 2.0 & 4.24 & 5.35 \\
\hline 5.2 & 5.91 & 8.73 & 5.6 & 5.62 & 8.70 & 4.6 & 5.62 & 6.32 & 5.4 & 5.46 & 7.12 \\
\hline 7.8 & 5.48 & 6.99 & 8.6 & 4.93 & 5.31 & 7.3 & 4.05 & 4.40 & 8.0 & 5.89 & 8.24 \\
\hline 10.2 & 5.50 & 6.92 & 11.5 & 5.60 & 7.39 & 10.1 & 5.03 & 5.63 & 10.6 & 4.76 & 5.38 \\
\hline 12.7 & 5.68 & 8.03 & 14.5 & 5.36 & 7.10 & 12.8 & 5.83 & 6.50 & 13.1 & 6.25 & 7.93 \\
\hline
\end{tabular}




\subsection{Concrete-Soil Half-Cell Experiments to Determine the Diffusion of lodine, Rhenium, and Technetium from Fractured Concrete into Soil}

Two sets of diffusion experiments were initiated during FY 2008 using fractured concrete-soil halfcells. Experimental conditions in these tests are similar to the concrete-soil and soil-soil half-cell experiments conducted previously (FYs 1998-2007). As previously discussed, the concrete composition for burial encasement specified in Specification for Concrete Encasement for Contact-Handled Category 3 Waste $^{1}$ was used as the basis for preparing a concrete for fabrication of test specimens (Table 3.1 and Table 3.2).

Concrete half-cell specimens were spiked with I and Re (set 1) and Tc (set 2) to achieve a measurable diffusion profile in the soil part of the half-cell. Concrete monoliths were prepared with mix components added in the following order: water, steel (if applicable), coarse aggregate, fine aggregate, fly ash, cement, Polyheed 997, and MB AE 90. The concrete was mixed at medium speed using a Hobart threespeed, bench-top mixer in a 4-L steel bowl. The concrete molds for casting specimens were fabricated from Schedule 40 PVC piping material. Gaskets were glued to the bottom of the molds and leak tested before use. The PVC forms were pre-treated with form release, a liquid that allows the concrete specimen to release easily from the mold. The first treatment was applied 3 days prior and the second treatment was applied a few hours prior to adding wet concrete to the molds. The PVC molds were filled in the vertical position. After filling, the molds were lightly tapped on the laboratory bench until a significant decrease in the release of air bubbles was observed. The forms were stored in a humidity chamber for 28 days to provide moisture while the concrete set. The concrete monoliths were subsequently removed from the molds and half of the monoliths were carbonated (if applicable) by soaking the cores for 7 days in a saturated sodium-bicarbonate solution. The characteristics of the specimens used are listed in Table 5.1.

The diffusion tests are being conducted under unsaturated conditions at $4 \%, 7 \%$, and $15 \%$ (moisture content by weight). One concrete core of each composition was encased in a Schedule 40, 24-cm-long PVC pipe. The volume of each pipe was filled with Hanford Site sediment at the respective moisture content that was spiked with I and Re to attain a measurable diffusion profile into the fractured concrete. The ends of each pipe were machined and fit with o-ring gaskets to ensure that the test cells were sealed. The diffusion tests will be allowed to set horizontally and undisturbed for the test duration, 1 or 2 years, with periodic rotation of the cell by 90 degrees.

In FYs 2009 and 2010, the soil and concrete half-cells will be sectioned and subjected to 1:1 water extractions to measure the concentration of I, Re, and Tc using ICP-MS and ICP-OES in soil and concrete thin slices. From the concentration data, probit plots will be constructed and the diffusion coefficients for these contaminants will be determined. We will correlate the calculated diffusion coefficients with the degree of microcracking in the cement specimens used in the half-cell experiments. The porosity of the concrete will be measured using mercury porosimetry.

${ }^{1}$ 1998, Waste Management (Unpublished) 
Table 5.1. Characteristics of Concrete Specimens Used in Concrete-Soil Half-Cells

\begin{tabular}{|c|c|c|c|c|c|c|c|c|c|c|}
\hline Core ID & $\begin{array}{l}\text { Length } \\
\text { (cm) }\end{array}$ & $\begin{array}{l}\text { Diameter } \\
(\mathrm{cm})\end{array}$ & $\mathrm{r}^{2}$ & $\begin{array}{c}\text { Surface } \\
\text { Area } \\
\left(\mathrm{cm}^{2}\right)\end{array}$ & $\begin{array}{c}\text { Volume } \\
\left(\mathrm{cm}^{3}\right)\end{array}$ & $\begin{array}{l}\text { Weight } \\
\text { (g) }\end{array}$ & $\begin{array}{l}\text { Density } \\
\left(\mathrm{g} / \mathrm{cm}^{3}\right)\end{array}$ & $\begin{array}{l}\text { Collodial } \\
\text { Iron }(\%)\end{array}$ & Carbonated & $\begin{array}{c}\text { Moisture } \\
\text { Content } \\
(\%)\end{array}$ \\
\hline \multicolumn{11}{|c|}{ Concrete Half-Cells Containing Iodine and Rhenium } \\
\hline C-08-5-0-501 & 3.92 & 4.32 & 4.66 & 82.37 & 57.31 & 137.08 & 2.39 & 0 & $\mathrm{~N}$ & 4 \\
\hline C-08-5-0-502 & 3.94 & 4.31 & 4.64 & 82.48 & 57.43 & 137.23 & 2.39 & 0 & $\mathrm{~N}$ & 7 \\
\hline C-08-5-0-503 & 4.13 & 4.32 & 4.67 & 85.35 & 60.52 & 145.80 & 2.41 & 0 & $\mathrm{~N}$ & 15 \\
\hline C-08-5-0-504 & 4.00 & 4.32 & 4.65 & 83.43 & 58.45 & 141.89 & 2.43 & 0 & $\mathrm{Y}$ & 4 \\
\hline C-08-5-0-505 & 3.86 & 4.32 & 4.66 & 81.68 & 56.55 & 138.20 & 2.44 & 0 & $\mathrm{Y}$ & 7 \\
\hline C-08-5-0-507 & 3.99 & 4.31 & 4.65 & 83.28 & 58.29 & 141.02 & 2.42 & 0 & Y & 15 \\
\hline C-08-5-4-526 & 3.86 & 4.32 & 4.67 & 81.77 & 56.65 & 136.50 & 2.41 & 4 & $\mathrm{~N}$ & 4 \\
\hline C- $-08-5-4-527$ & 4.14 & 4.32 & 4.66 & 85.43 & 60.61 & 145.87 & 2.41 & 4 & $\mathrm{~N}$ & 7 \\
\hline C-08-5-4-528 & 3.80 & 4.32 & 4.67 & 81.02 & 55.83 & 134.05 & 2.40 & 4 & $\mathrm{~N}$ & 15 \\
\hline C-08-5-4-530 & 3.96 & 4.33 & 4.68 & 83.27 & 58.26 & 139.27 & 2.39 & 4 & $\mathrm{Y}$ & 4 \\
\hline C-08-5-4-531 & 4.11 & 4.32 & 4.68 & 85.16 & 60.31 & 145.56 & 2.41 & 4 & Y & 7 \\
\hline C- $08-5-4-532$ & 3.85 & 4.32 & 4.66 & 81.45 & 56.31 & 134.81 & 2.39 & 4 & $\mathrm{Y}$ & 15 \\
\hline C- $-08-5-8-552$ & 4.12 & 4.31 & 4.64 & 84.94 & 60.08 & 146.32 & 2.44 & 8 & $\mathrm{~N}$ & 4 \\
\hline C-08-5-8-553 & 4.04 & 4.32 & 4.67 & 84.28 & 59.36 & 145.89 & 2.46 & 8 & $\mathrm{~N}$ & 7 \\
\hline C-08-5-8-554 & 3.89 & 4.30 & 4.62 & 81.63 & 56.53 & 138.57 & 2.45 & 8 & $\mathrm{~N}$ & 15 \\
\hline C-08-5-8-555 & 3.95 & 4.30 & 4.62 & 82.40 & 57.36 & 140.05 & 2.44 & 8 & $\mathrm{Y}$ & 4 \\
\hline C-08-5-8-556 & 3.92 & 4.30 & 4.63 & 82.12 & 57.05 & 140.48 & 2.46 & 8 & $\mathrm{Y}$ & 7 \\
\hline C-08-5-8-557 & 4.07 & 4.30 & 4.62 & 84.05 & 59.13 & 145.19 & 2.46 & 8 & $\mathrm{Y}$ & 15 \\
\hline C-08-5-12-576 & 4.05 & 4.31 & 4.65 & 84.03 & 59.10 & 144.99 & 2.45 & 12 & $\mathrm{~N}$ & 4 \\
\hline C-08-5-12-577 & 4.08 & 4.31 & 4.64 & 84.36 & 59.46 & 144.82 & 2.44 & 12 & $\mathrm{~N}$ & 7 \\
\hline C-08-5-12-578 & 3.84 & 4.31 & 4.64 & 81.11 & 55.96 & 137.24 & 2.45 & 12 & $\mathrm{~N}$ & 15 \\
\hline C- $08-5-12-580$ & 4.06 & 4.31 & 4.65 & 84.27 & 59.36 & 144.46 & 2.43 & 12 & $\mathrm{Y}$ & 4 \\
\hline C- $08-5-12-581$ & 4.29 & 4.31 & 4.64 & 87.17 & 62.49 & 153.33 & 2.45 & 12 & $\mathrm{Y}$ & 7 \\
\hline C-08-5-12-552 & 3.92 & 4.31 & 4.64 & 82.11 & 57.04 & 141.77 & 2.49 & 12 & $\mathrm{Y}$ & 15 \\
\hline \multicolumn{11}{|c|}{ Concrete Half-Cells Containing Technetium } \\
\hline Tc-C-08-5-0-603 & 3.51 & 4.28 & 4.59 & 76.07 & 50.60 & 112.52 & 2.22 & 0 & $\mathrm{~N}$ & 4 \\
\hline Tc-C-08-5-0-604 & 3.87 & 4.30 & 4.62 & 81.26 & 56.13 & 124.77 & 2.22 & 0 & $\mathrm{~N}$ & 7 \\
\hline Tc-C-08-5-0-605 & 4.00 & 4.30 & 4.63 & 83.24 & 58.25 & 129.15 & 2.22 & 0 & $\mathrm{~N}$ & 15 \\
\hline Tc-C-08-5-4-623 & 4.06 & 4.31 & 4.63 & 83.97 & 59.04 & 131.09 & 2.22 & 4 & $\mathrm{~N}$ & 4 \\
\hline Tc-C-08-5-4-624 & 3.97 & 4.30 & 4.63 & 82.76 & 57.74 & 127.84 & 2.21 & 4 & $\mathrm{~N}$ & 7 \\
\hline Tc-C-08-5-4-625 & 3.69 & 4.31 & 4.64 & 79.08 & 53.76 & 119.01 & 2.21 & 4 & $\mathrm{~N}$ & 15 \\
\hline Tc-C-08-5-8-641 & 3.52 & 4.30 & 4.63 & 76.70 & 51.22 & 113.02 & 2.21 & 8 & $\mathrm{~N}$ & 4 \\
\hline Tc-C-08-5-8-643 & 3.59 & 4.31 & 4.64 & 77.65 & 52.23 & 115.88 & 2.22 & 8 & $\mathrm{~N}$ & 7 \\
\hline Tc-C-08-5-8-644 & 3.78 & 4.31 & 4.64 & 80.31 & 55.09 & 122.51 & 2.22 & 8 & $\mathrm{~N}$ & 15 \\
\hline Tc-C-08-5-12-661 & 3.73 & 4.31 & 4.64 & 79.62 & 54.35 & 122.34 & 2.25 & 12 & $\mathrm{~N}$ & 4 \\
\hline Tc-C-08-5-12-662 & 3.70 & 4.31 & 4.64 & 79.32 & 54.03 & 122.08 & 2.26 & 12 & $\mathrm{~N}$ & 7 \\
\hline Tc-C-08-5-12-664 & 3.74 & 4.31 & 4.65 & 79.84 & 54.59 & 123.09 & 2.25 & 12 & $\mathrm{~N}$ & 15 \\
\hline
\end{tabular}




\subsection{Moisture Gradient Within Concrete-Soil Half-Cell Tests}

A set of concrete-soil half-cell experiments were initiated during FY 2008. Experimental conditions in these tests are similar to the concrete-soil and soil-soil half-cell experiments conducted previously (from FY 1998 through 2007). As previously discussed, the concrete composition for burial encasement specified in Specification for Concrete Encasement for Contact-Handled Category 3 Waste ${ }^{1}$ was used as the basis for preparing a concrete for fabrication of test specimens (Table 3.1 and Table 3.2).

Concrete monoliths were prepared with mix components added in the following order: water, coarse aggregate, fine aggregate, fly ash, cement, Polyheed 997, and MB AE 90. The concrete was mixed at medium speed using a Hobart three-speed, bench-top mixer in a 4-L steel bowl. The concrete molds for casting specimens were fabricated from Schedule 40 PVC piping material. Gaskets were glued to the bottom of the molds and leak tested before use. The PVC forms were pre-treated with form release, a liquid that allows the concrete specimen to release easily from the mold. The first treatment was applied 3 days prior and the second treatment was applied a few hours prior to adding wet concrete to the molds. The PVC molds were filled in the vertical position. After filling, the molds were lightly tapped on the laboratory bench until a significant decrease in the release of air bubbles was observed. The forms were stored in a humidity chamber for 28 days to provide moisture while the concrete set. The characteristics of the specimens used are listed in Table 6.1.

Table 6.1. Characteristics of Cement Specimens Used in Fractured Concrete-Soil Half-Cell Tests

\begin{tabular}{ccccccccc}
\hline Core ID & $\begin{array}{c}\text { Length } \\
(\mathrm{cm})\end{array}$ & $\begin{array}{c}\text { Diameter } \\
(\mathrm{cm})\end{array}$ & $\mathrm{r}^{2}$ & $\begin{array}{c}\text { Surface } \\
\text { Area } \\
\left(\mathrm{cm}^{2}\right)\end{array}$ & $\begin{array}{c}\text { Volume } \\
\left(\mathrm{cm}^{3}\right)\end{array}$ & $\begin{array}{c}\text { Weight } \\
(\mathrm{g})\end{array}$ & $\begin{array}{c}\text { Density } \\
\left(\mathrm{g} / \mathrm{cm}^{3}\right)\end{array}$ & $\begin{array}{c}\text { Moisture } \\
\text { Content } \\
(\%)\end{array}$ \\
\hline $\mathrm{C}-08-6-0-302$ & 4.222 & 4.322 & 4.670 & 86.668 & 61.941 & 135.997 & 2.20 & 4 \\
$\mathrm{C}-08-6-0-305$ & 4.17 & 4.329 & 4.685 & 86.149 & 61.376 & 135.73 & 2.21 & 7 \\
$\mathrm{C}-08-6-0-314$ & 4.033 & 4.327 & 4.681 & 84.233 & 59.305 & 130.768 & 2.21 & 15 \\
\hline
\end{tabular}

The half-cells tests are being conducted under unsaturated conditions at $4 \%, 7 \%$, and $15 \%$ (moisture content by weight). One concrete core was encased in a Schedule 40, 24-cm-long PVC pipe. The volume of each pipe was filled with Hanford Site sediment at the respective moisture content. The ends of each pipe were machined and fit with o-ring gaskets to ensure that the test cells were sealed. The half-cell tests will be allowed to set horizontally and undisturbed for 1 year, with periodic rotation of the cell by 90 degrees. In FY 2009, the moisture content distribution profile within the soil half-cell will be determined.

\footnotetext{
${ }^{1}$ 1998, Waste Management (Unpublished)
} 


\subsection{Concrete-Soil Half-Cell Experiments to Determine the Effects of Iron on the Diffusion of Technetium}

A set of diffusion experiments were initiated during FY 2007 using concrete-soil half-cells containing Tc. Experimental conditions in these tests are similar to the concrete-soil and soil-soil half-cell experiments conducted previously (from FY 1998 through 2007). As previously discussed, the concrete composition for burial encasement specified in Specification for Concrete Encasement for ContactHandled Category ${ }^{1} 3$ Waste $^{(\mathrm{a})}$ was used as the basis for preparing a concrete for fabrication of test specimens (Table 3.1 and Table 3.2).

Concrete half-cell specimens were spiked with Tc to achieve a measurable diffusion profile in the soil part of the half-cell. Concrete monoliths were prepared with mix components added in the following order: water, steel (if applicable), coarse aggregate, fine aggregate, fly ash, cement, Polyheed 997, and MB AE 90. The concrete was mixed at medium speed using a Hobart three-speed, bench-top mixer in a 4-L steel bowl. The concrete molds for casting specimens were fabricated from Schedule 40 PVC piping material. Gaskets were glued to the bottom of the molds and leak tested before use. The PVC forms were pre-treated with form release, a liquid that allows the concrete specimen to release easily from the mold. The first treatment was applied 3 days prior and the second treatment was applied a few hours prior to adding wet concrete to the molds. The PVC molds were filled in the vertical position. After filling, the molds were lightly tapped on the laboratory bench until a significant decrease in the release of air bubbles was observed. The forms were stored in a humidity chamber for 28 days to provide moisture while the concrete set. The concrete monoliths were subsequently removed from the molds. The characteristics of the specimens used are listed in Table 7.1.

Table 7.1. Characteristics of Cement Specimens Used in Fractured Concrete-Soil Half-Cell Tests

\begin{tabular}{ccccccc}
\hline & $\begin{array}{c}\text { Concrete } \\
\text { Treatment }\end{array}$ & $\begin{array}{c}\text { Tc } \\
\text { Concentration } \\
(\mathrm{mg} / \mathrm{g} \text { concrete })\end{array}$ & $\begin{array}{c}\text { Height of } \\
\text { Concrete } \\
\text { Half-Cell } \\
(\mathrm{cm})\end{array}$ & $\begin{array}{c}\text { Volume of } \\
\text { Concrete Half- } \\
\text { Cell }\left(\mathrm{cm}^{3}\right)\end{array}$ & $\begin{array}{c}\text { Density } \\
\text { Concrete } \\
\left(\mathrm{g} / \mathrm{cm}^{3}\right)\end{array}$ & $\begin{array}{c}\text { Soil Moisture } \\
\text { Content (\%) }\end{array}$ \\
\hline Tc-C-4-0-204 & $0 \% \mathrm{Fe}$ & 0.074 & 4.169 & 61.05 & 2.04 & 4 \\
Tc-C-4-4-213 & $4 \% \mathrm{Fe}$ & 0.082 & 4.26 & 62.195 & 2.23 & 4 \\
Tc-C-4-0-203 & $0 \% \mathrm{Fe}$ & 0.078 & 4.343 & 63.392 & 2.07 & 7 \\
Tc-C-4-4-212 & $4 \% \mathrm{Fe}$ & 0.082 & 4.226 & 61.77 & 2.23 & 7 \\
Tc-C-4-0-202 & $0 \% \mathrm{Fe}$ & 0.079 & 4.389 & 64.183 & 2.08 & 15 \\
Tc-C-4-4-211 & $4 \% \mathrm{Fe}$ & 0.084 & 4.367 & 63.816 & 2.23 & 15 \\
\hline
\end{tabular}

Diffusion tests were conducted under unsaturated conditions at $4 \%, 7 \%$, and $15 \%$ (moisture content by weight). One concrete core of each composition was encased in a Schedule 40, 24-cm-long PVC pipe. The volume of each pipe was filled with Hanford Site sediment at the respective moisture content. The ends of each pipe were machined and fit with o-ring gaskets to ensure that the test cells were sealed. The diffusion tests will be allowed to set horizontally and undisturbed for 698 days with periodic rotation of the cell by 90 degrees.

\footnotetext{
${ }^{1}$ 1998, Waste Management (Unpublished)
} 
At the conclusion of the test period in FY 2008, the end caps of the cells were removed and the sediment was extruded at approximately $1-\mathrm{cm}$ intervals along the length of the half-cell (Figure 4.1). Concrete half-cells were thin-sliced using a Buehler slow-speed saw fitted with a diamond blade. Cutting was done without water cooling to prevent the leaching of soluble Tc during the cutting process. The concrete slices were then ground using an agate mortar and pestle. The soil and concrete half-cells were sectioned and subjected to 1:1 deionized water extractions. The concentration of Tc were measured using ICP-MS in soil and concrete thin slices.

\subsection{Concentration Profile Results and Discussion}

The concentration profiles for Tc from concrete-soil half-cell diffusion experiments are shown in Figure 7.1 and Figure 7.2. The Tc concentration profile for sediments at $4 \%$ and $7 \%$ moisture content exhibited greater concentrations for those in contact with concrete cores without iron (Figure 7.1). In the absence of iron, the concentration of Tc in sediment at $4 \%$ moisture content initiated at $7.96 \times 10^{-6} \mathrm{mg} / \mathrm{g}$ and gradually decreased to $1.96 \times 10^{-6} \mathrm{mg} / \mathrm{g}$. In the presence of iron, the concentration of Tc in the sediment at the concrete-soil interface was $3.29 \times 10^{-6} \mathrm{mg} / \mathrm{g}, 41 \%$ less than that quantified in the concretesoil half-cell that did not contain iron in the concrete monolith. The concentration decreased over the length of the soil profile to $5.12 \times 10^{-7} \mathrm{mg} / \mathrm{g}$. At $7 \%$ moisture content and in the absence of iron, the concentration of Tc in sediment initiated at $1.24 \times 10^{-6} \mathrm{mg} / \mathrm{g}$. Contrary to the soil profile for Tc at $4 \%$ moisture content, at $7 \%$ the concentration of Tc in the sediment displayed a slight increase as a function of increasing distance from the concrete-soil interface. The concentration of Tc in the soil section furthest from the interface, $9.5 \mathrm{~cm}$, was $2.74 \times 10^{-7} \mathrm{mg} / \mathrm{g}$ Tc. This slight increase through the soil profile also was observed for the concrete-soil half-cell at $7 \%$ moisture content for concrete containing iron. In the presence of iron, the concentration of Tc initiated at $1.29 \times 10^{-6} \mathrm{mg} / \mathrm{g}$ and increased over the length of the half-cell to a maximum concentration of $1.89 \times 10^{-6} \mathrm{mg} / \mathrm{g}$ Tc at $9.5 \mathrm{~cm}$. The concentration of Tc throughout the soil profile was $\sim 65 \%$ lower in the concrete-soil half-cell that contained iron in the concrete monolith than in the one that did not contain iron at $7 \%$ moisture content.

The concentration profiles for sediments at $15 \%$ moisture content displayed an increase in concentration within the first $4 \mathrm{~cm}$ of the soil profile and then a general decrease in Tc concentration (Table 7.2). However, the trend was not smooth and displayed several deviations in concentration. Additionally, the concentration of Tc in the soil from the concrete-soil half-cell that contained iron in the concrete monolith was greater than the one that did not contain iron. In the absence of iron, the Tc concentration initiated in the soil profile at $5.17 \times 10^{-6} \mathrm{mg} / \mathrm{g}$, increased to a maximum concentration of $5.45 \times 10^{-6} \mathrm{mg} / \mathrm{g}$, and then decreased to $5.19 \times 10^{-6} \mathrm{mg} / \mathrm{g}$. In the presence of $4 \%$ iron, the Tc concentration initiated in the soil profile at $6.95 \times 10^{-6} \mathrm{mg} / \mathrm{g}$, increased to a maximum concentration of $7.02 \times 10^{-6} \mathrm{mg} / \mathrm{g}$, and then decreased to $5.95 \times 10^{-6} \mathrm{mg} / \mathrm{g}$. 

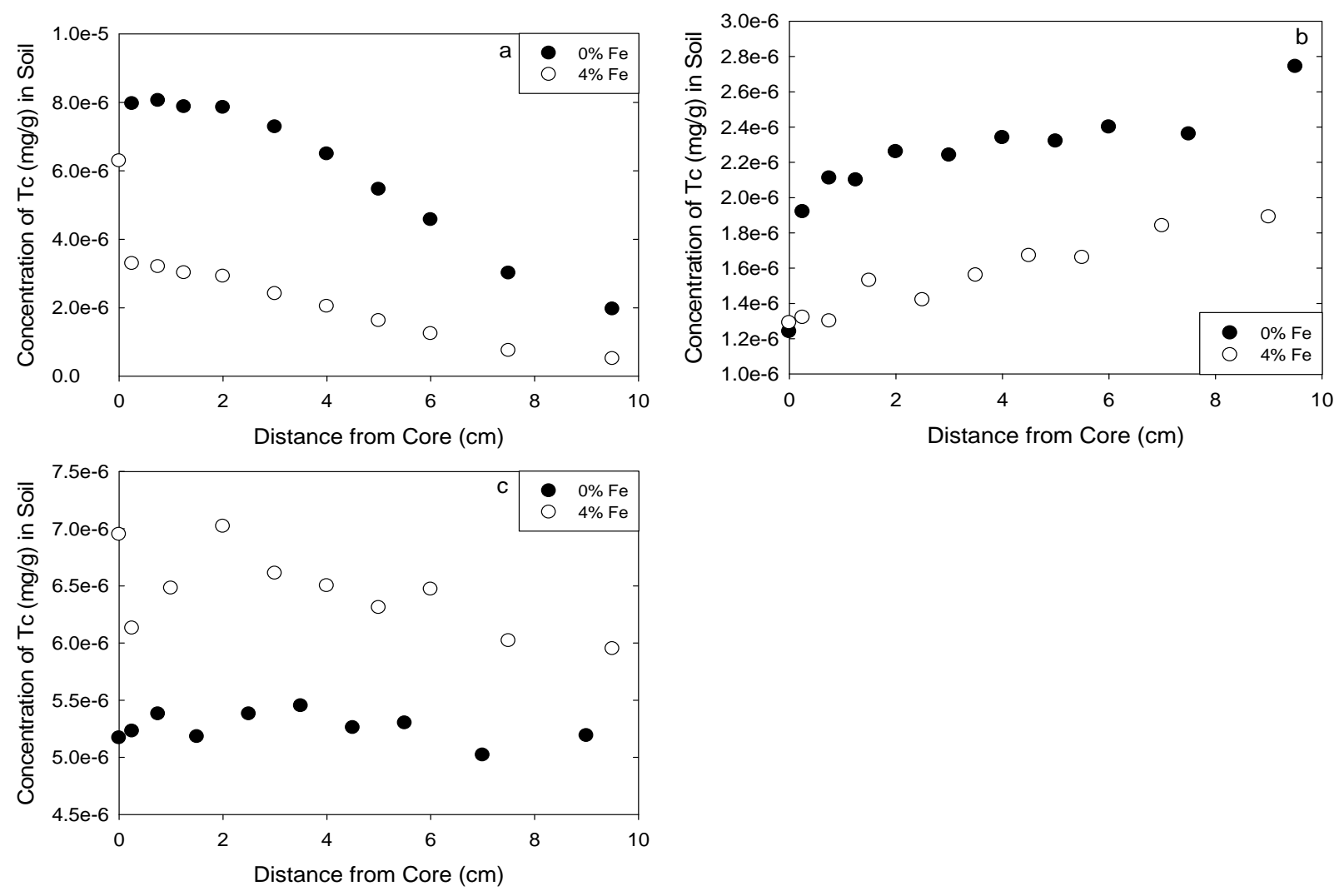

Figure 7.1. Concentration Profiles for Soil Half-Cell Tc Profiles. a) 4\%, b) 7\%, and c) 15\% moisture content by weight containing non-carbonated concrete monoliths with and without iron.

Table 7.2. Concentration of Technetium (mg/g) for Soil Half-Cell Profiles at 4\%, $7 \%$, and $15 \%$ Moisture Content

\begin{tabular}{|c|c|c|c|c|c|c|c|c|}
\hline $\begin{array}{l}\text { Distance } \\
\text { from } \\
\text { Core, } \mathrm{cm}\end{array}$ & $\begin{array}{l}4 \% \mathrm{MC}- \\
0 \% \text { Iron }\end{array}$ & $\begin{array}{l}4 \% \mathrm{MC}- \\
4 \% \text { Iron }\end{array}$ & $\begin{array}{l}7 \% \mathrm{MC}- \\
0 \% \text { Iron } \\
\end{array}$ & $\begin{array}{l}7 \% \mathrm{MC}- \\
4 \% \text { Iron }\end{array}$ & $\begin{array}{l}\text { Distance } \\
\text { from } \\
\text { Core, } \mathrm{cm}\end{array}$ & $\begin{array}{c}15 \% \text { MC- } \\
0 \% \text { Iron }\end{array}$ & $\begin{array}{c}\text { Distance } \\
\text { from } \\
\text { Core, } \mathrm{cm}\end{array}$ & $\begin{array}{c}15 \% \mathrm{MC}- \\
4 \% \text { Iron } \\
\end{array}$ \\
\hline 9.5 & $1.96 \mathrm{E}-06$ & $5.12 \mathrm{E}-07$ & $2.74 \mathrm{E}-06$ & $1.89 \mathrm{E}-06$ & 9.0 & $5.19 \mathrm{E}-06$ & 9.5 & $5.95 \mathrm{E}-06$ \\
\hline 7.5 & $3.01 \mathrm{E}-06$ & $7.46 \mathrm{E}-07$ & $2.36 \mathrm{E}-06$ & $1.84 \mathrm{E}-06$ & 7.0 & $5.02 \mathrm{E}-06$ & 7.5 & $6.02 \mathrm{E}-06$ \\
\hline 6 & $4.57 \mathrm{E}-06$ & $1.24 \mathrm{E}-06$ & $2.40 \mathrm{E}-06$ & $1.66 \mathrm{E}-06$ & 5.5 & $5.30 \mathrm{E}-06$ & 6.0 & $6.47 \mathrm{E}-06$ \\
\hline 5 & $5.46 \mathrm{E}-06$ & $1.62 \mathrm{E}-06$ & $2.32 \mathrm{E}-06$ & $1.67 \mathrm{E}-06$ & 4.5 & $5.26 \mathrm{E}-06$ & 5.0 & $6.31 \mathrm{E}-06$ \\
\hline 4 & $6.49 \mathrm{E}-06$ & $2.04 \mathrm{E}-06$ & $2.34 \mathrm{E}-06$ & $1.56 \mathrm{E}-06$ & 3.5 & $5.45 \mathrm{E}-06$ & 4.0 & $6.50 \mathrm{E}-06$ \\
\hline 3 & $7.28 \mathrm{E}-06$ & $2.41 \mathrm{E}-06$ & $2.24 \mathrm{E}-06$ & $1.42 \mathrm{E}-06$ & 2.5 & $5.38 \mathrm{E}-06$ & 3.0 & $6.61 \mathrm{E}-06$ \\
\hline 2 & $7.85 \mathrm{E}-06$ & $2.92 \mathrm{E}-06$ & $2.26 \mathrm{E}-06$ & $1.53 \mathrm{E}-06$ & 1.5 & $5.18 \mathrm{E}-06$ & 2.0 & 7.02E-06 \\
\hline 1.25 & $7.87 \mathrm{E}-06$ & $3.02 \mathrm{E}-06$ & $2.10 \mathrm{E}-06$ & $1.30 \mathrm{E}-06$ & 0.8 & 5.38E-06 & 1.0 & $6.48 \mathrm{E}-06$ \\
\hline 0.75 & $8.05 \mathrm{E}-06$ & $3.20 \mathrm{E}-06$ & $2.11 \mathrm{E}-06$ & $1.32 \mathrm{E}-06$ & 0.3 & $5.23 \mathrm{E}-06$ & 0.3 & $6.13 \mathrm{E}-06$ \\
\hline 0.25 & $7.96 \mathrm{E}-06$ & $3.29 \mathrm{E}-06$ & $1.92 \mathrm{E}-06$ & $1.29 \mathrm{E}-06$ & 0.0 & $5.17 \mathrm{E}-06$ & 0.0 & $6.95 \mathrm{E}-06$ \\
\hline 0 & N/A & $6.29 \mathrm{E}-06$ & $1.24 \mathrm{E}-06$ & N/A & & & & \\
\hline
\end{tabular}


The total concentration of Tc recovered in the concrete half-cells were comparable for concrete monoliths containing iron and those without iron (Table 7.3). The normalized concentration profiles for concrete half-cells all indicate greater concentrations of Tc for half-cells in which the concrete did not contain iron (Figure 7.2). At 4\% moisture content, the concentration profile for Tc in the absence of iron initiates at $0.6 \mu \mathrm{g} \mathrm{Tc} / \mathrm{g}$ concrete. The concentration displays a linear decrease over the first $10 \mathrm{~mm}$ of the monolith, followed by a more gradual decrease over the subsequent $10 \mathrm{~mm}$ of concrete monolith. A similar behavior is observed in the presence of iron, except that the concentration of Tc within the monolith is less than that measured in the presence of iron. The interfacial concentration is $0.46 \mu \mathrm{g} \mathrm{Tc} / \mathrm{g}$ concrete and it exhibits a rapid decrease to $\sim 0.2 \mu \mathrm{g}$ Tc/g concrete, which is sustained throughout the remaining $10 \mathrm{~mm}$ of monolith.

The distribution and behavior of Tc was similar for concrete monoliths at $7 \%$ and $15 \%$ moisture content. In the absence of iron, the concentration near the interface was $\sim 0.3 \mu \mathrm{g} \mathrm{Tc} / \mathrm{g}$ concrete. The concentration of $\mathrm{Tc}$ decreased slightly throughout the length of the cores to $\sim 0.2 \mu \mathrm{g} \mathrm{Tc} / \mathrm{g}$ concrete. In the presence of iron, the concentration near the interface was $\sim 0.25-0.3 \mu \mathrm{g} \mathrm{Tc} / \mathrm{g}$ concrete. The concentration again decreased throughout the length of the core, but the decrease was greater than it was in the absence of iron. In the presence of iron the concentration decreased to a minimum of $\sim 0.15 \mu \mathrm{g} \mathrm{Tc} / \mathrm{g}$ concrete, 10 to $15 \mathrm{~mm}$ from the concrete-soil interface. These results contrast with those previous presented by Mattigod et al. (2001), which quantified the diffusion of I and Tc from concrete monoliths containing iron at 4\% and 7\% moisture contents, sampling at 64 and 169 days. Results by Mattigod et al. (2001) indicated that the inclusion of iron did not significantly influence the diffusion of I or Tc and/or Re. The significantly short test duration for previous half-cell experiments may have limited the observed effect of iron on Tc diffusion. This will be confirmed by the two sets of half-cell tests initiated in FY 2008 (Section 3.0), which will continue for test periods of 1 and 2 years. Additionally, in FY 2009 the porosity of the concrete will be measured using mercury porosimetry and the degree of microcracking within the concrete monoliths will be evaluated using scanning electron microscopy.

It has also been previously suggested that diffusion increased with increasing water content (Mattigod et al. 2001). Subsequent tests by Wellman et al. (2006b), which were two to six times longer in duration, presented conflicting results that did not show an increase in diffusion as a function of water content. Results presented here agree with previous findings by Wellman et al. (2006b). It is, again, possible that the significantly shorter test duration for the half-cells presented by Mattigod et al. (2001) may affect the observed behaviors given a longer time frame. Alternatively, it may be possible that the moisture content within the half-cell tests is not maintained during the longer time frames. These possible scenarios will be evaluated through half-cell tests initiated in FY 2008 (Sections 3.0 and 6.0), which will continue for test periods of 1 to 2 years. 

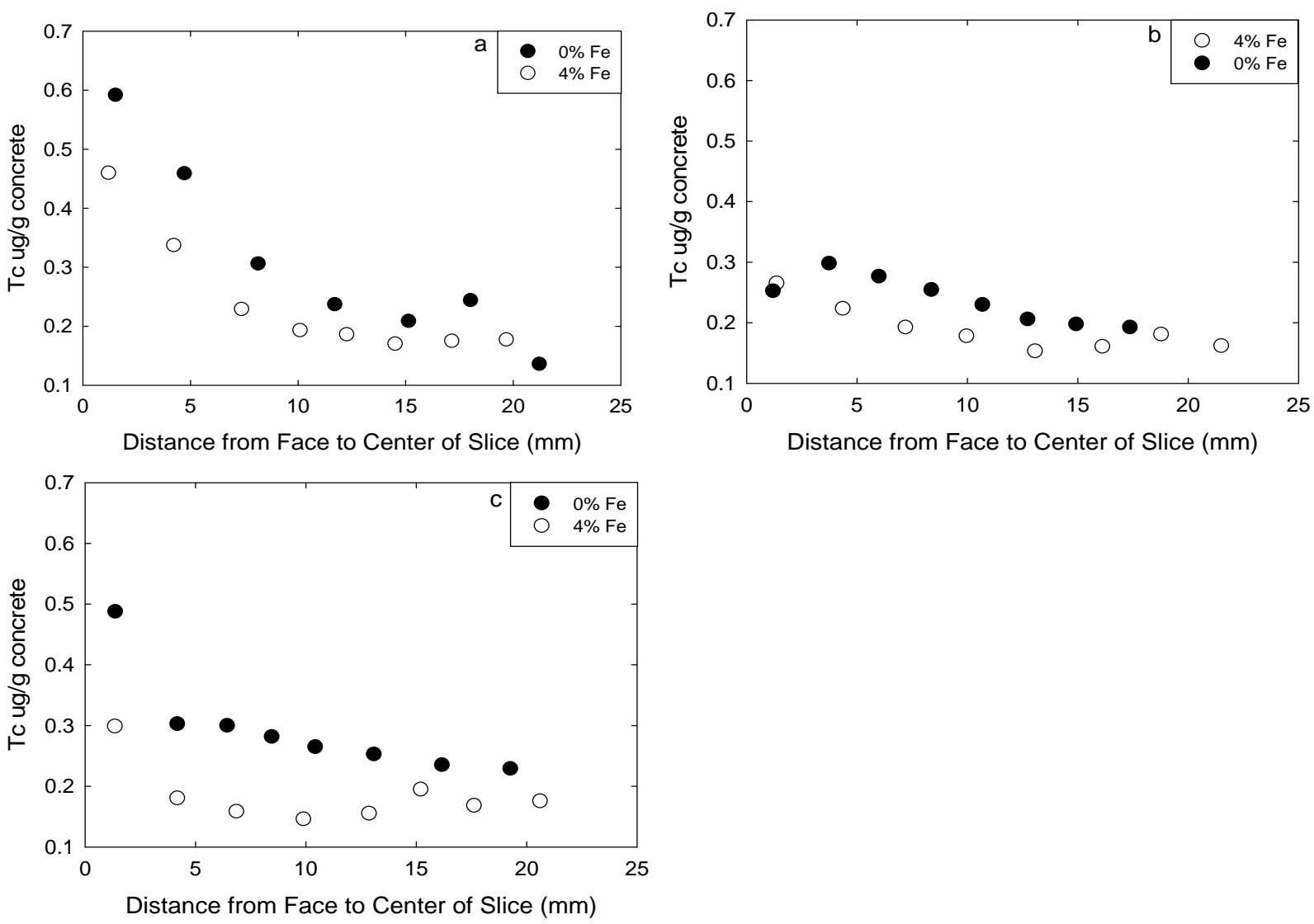

Figure 7.2. Concentration Profiles for Concrete Half-Cell Tc Profiles. a) 4\%, b) 7\%, and c) $15 \%$ moisture content by weight in non-carbonated concrete monoliths with and without iron.

Table 7.3. Concentration of Technetium $(\mu \mathrm{g} / \mathrm{g})$ for Concrete Half-Cell Profiles at $4 \%, 7 \%$, and $15 \%$ Moisture Content

\begin{tabular}{|c|c|c|c|c|c|c|c|c|c|c|c|}
\hline \multicolumn{2}{|c|}{$\begin{array}{l}4 \% \text { Soil- } \\
0 \% \text { Iron }\end{array}$} & \multicolumn{2}{|c|}{$\begin{array}{l}4 \% \text { Soil- } \\
4 \% \text { Iron }\end{array}$} & \multicolumn{2}{|c|}{$\begin{array}{l}7 \% \text { Soil- } \\
0 \% \text { Iron }\end{array}$} & \multicolumn{2}{|c|}{$\begin{array}{l}7 \% \text { Soil- } \\
4 \% \text { Iron }\end{array}$} & \multicolumn{2}{|c|}{$\begin{array}{c}15 \% \text { Soil- } \\
0 \% \text { Iron }\end{array}$} & \multicolumn{2}{|c|}{$\begin{array}{c}15 \% \text { Soil- } \\
4 \% \text { Iron }\end{array}$} \\
\hline $\begin{array}{l}\text { Distance } \\
\text { from }\end{array}$ & & $\begin{array}{l}\text { Distance } \\
\text { from }\end{array}$ & & $\begin{array}{l}\text { Distance } \\
\text { from }\end{array}$ & & $\begin{array}{l}\text { Distance } \\
\text { from }\end{array}$ & & $\begin{array}{l}\text { Distance } \\
\text { from }\end{array}$ & & $\begin{array}{l}\text { Distance } \\
\text { from }\end{array}$ & \\
\hline $\begin{array}{c}\text { Interface, } \\
\mathrm{mm}\end{array}$ & $\begin{array}{c}\text { Tc, } \\
\mu \mathrm{g} / \mathrm{g}\end{array}$ & $\begin{array}{c}\text { Interface, } \\
\mathrm{mm}\end{array}$ & $\begin{array}{c}\mathrm{Tc}, \\
\mu \mathrm{g} / \mathrm{g}\end{array}$ & $\begin{array}{c}\text { Interface, } \\
\mathrm{mm}\end{array}$ & $\begin{array}{c}\text { Tc, } \\
\mu \mathrm{g} / \mathrm{g}\end{array}$ & $\begin{array}{c}\text { Interface, } \\
\mathrm{mm}\end{array}$ & $\begin{array}{c}\mathrm{Tc}, \\
\mu \mathrm{g} / \mathrm{g}\end{array}$ & $\begin{array}{c}\text { Interface, } \\
\mathrm{mm}\end{array}$ & $\begin{array}{c}\mathrm{Tc}, \\
\mu \mathrm{g} / \mathrm{g}\end{array}$ & $\begin{array}{c}\text { Interface, } \\
\mathrm{mm}\end{array}$ & $\begin{array}{c}\text { Tc, } \\
\mu \mathrm{g} / \mathrm{g}\end{array}$ \\
\hline 1.5 & 0.59 & 1.2 & 0.46 & 1.2 & 0.25 & 1.4 & 0.26 & 1.4 & 0.49 & 1.4 & 0.3 \\
\hline 4.7 & 0.46 & 4.3 & 0.34 & 3.8 & 0.3 & 4.4 & 0.22 & 4.2 & 0.3 & 4.2 & 0.18 \\
\hline 8.2 & 0.31 & 7.4 & 0.23 & 6 & 0.28 & 7.2 & 0.19 & 6.5 & 0.3 & 6.9 & 0.16 \\
\hline 11.7 & 0.24 & 10.1 & 0.19 & 8.4 & 0.25 & 10 & 0.18 & 8.5 & 0.28 & 9.9 & 0.15 \\
\hline 15.2 & 0.21 & 12.3 & 0.19 & 10.7 & 0.23 & 13.1 & 0.15 & 10.5 & 0.26 & 12.9 & 0.15 \\
\hline 18 & 0.24 & 14.5 & 0.17 & 12.8 & 0.21 & 16.1 & 0.16 & 13.1 & 0.25 & 15.2 & 0.19 \\
\hline 21.2 & 0.14 & 17.2 & 0.17 & 15 & 0.2 & 18.8 & 0.18 & 16.2 & 0.23 & 17.6 & 0.17 \\
\hline & & 19.7 & 0.18 & 17.4 & 0.19 & 21.5 & 0.16 & 19.3 & 0.23 & 20.6 & 0.17 \\
\hline Total & 2.19 & & 1.93 & & 1.91 & & 1.5 & & 2.34 & & 1.47 \\
\hline
\end{tabular}




\subsection{Reactivity of Limited Solubility U(VI)-Bearing Compounds in Concrete}

During FY 2004, Portland cement grout specimens were prepared with a U(VI) nitrate spike. The specimens were aged for various time spans ranging from 2 weeks to 1 year. A scanning electron microscopy/energy dispersive spectrometer was used to identify the uranium-bearing compounds that formed in the specimens. The uranium phases were identified to be those of soddyite, becquerelite, uranophane, and autunite. A literature search conducted in FY 2004 revealed that reliable thermochemical data are not available for these phases under conditions present in concrete waste forms. In FY 2006, we developed synthetic routes for the precipitation of pure uranium soddyite, becquerelite, and uranophane; natural autunite was used. In FY 2007 and FY 2008, we conducted solubility tests for these uranium-solid phases by conducting equilibrium solubility measurements under concrete porewater conditions. These data are expected to lead to better performance assessment modeling of uranium releases from waste-form concrete.

\subsection{Synthesis of U(VI) Phases}

All solutions were prepared with reagent-grade chemicals and $18 \mathrm{M} \Omega$ deionized water.

\subsubsection{Becquerelite Precipitation}

Direct precipitation of becquerelite was accomplished using the methods of Burns et al. (personal communication). Uranyl acetate $(0.313 \mathrm{~g})\left[\mathrm{UO}_{2}\left(\mathrm{CH}_{3} \mathrm{COO}\right)_{2} \cdot 2 \mathrm{H}_{2} \mathrm{O}\right]$ was combined with $0.05 \mathrm{~g}$ calcium carbonate $\left(\mathrm{CaCO}_{3}\right)$ in $4 \mathrm{~mL}$ of deionized water. The solution was placed in a Parr bomb and heated at $160^{\circ} \mathrm{C}$ for 50 hours. The light-mustard-colored precipitate was recovered from solution through centrifugation. The crystals were washed with four aliquots of boiling deionized water. The crystals were dried at room temperature until a constant weight was achieved.

\subsubsection{Soddyite Precipitation}

Direct precipitation of soddyite was conducted based on modified procedures presented by (Nguyen et al. 1992; Casas et al. 1997). Deionized water $(50 \mathrm{~mL})$ was boiled for 30 minutes while sparging with nitrogen to remove all carbon dioxide. A $0.15-\mathrm{M}$ uranyl nitrate, $\mathrm{UO}_{2}\left(\mathrm{NO}_{3}\right)_{2} \cdot 6 \mathrm{H}_{2} \mathrm{O}$ (Alfa Aesar) solution was prepared by adding $3.138 \mathrm{~g}$ uranyl nitrate to $40 \mathrm{~mL}$ of de-air water, which was boiled and sparged with nitrogen,. Sodium metasilicate $\left(1.77 \mathrm{~g}\right.$ ), $\mathrm{NaSiO}_{3} \cdot 9 \mathrm{H}_{2} \mathrm{O}$ (Alfa Aesar), was added to $10 \mathrm{~mL}$ of de-aired water, which was boiled and sparged with nitrogen, to prepare a 0.30 -M solution. The sodium metasilicate solution was added drop-wise, with stirring, to the $0.15-\mathrm{M}$ uranyl nitrate solution under anaerobic conditions. Concentrated ammonium hydroxide solution was added drop-wise stirring until the $\mathrm{pH}$ was within a range of 4.5 to 5.0. The solution was allowed to stir under anaerobic conditions for 100 hours. The crystals were washed with boiling deionized water. The solid phase was placed into a Parr reactor with $75 \mathrm{~mL}$ of boiling deionized water. The reactor was sealed and heated for 14 days at $130^{\circ} \mathrm{C}$. The resulting crystals were washed with boiling deionized water, recovered from solution through centrifugation, and dried at room temperature until a constant weight was achieved. 


\subsubsection{Uranophane Precipitation}

Direct precipitation of uranophane was accomplished using the methods of Burns et al. (personal communication). Uranyl acetate $(0.42 \mathrm{~g})\left[\mathrm{UO}_{2}\left(\mathrm{CH}_{3} \mathrm{COO}\right)_{2} \cdot 2 \mathrm{H}_{2} \mathrm{O}\right]$ was combined with $0.23 \mathrm{~g}$ of sodium metasilicate $\left[\mathrm{NaSiO}_{3} \cdot 9 \mathrm{H}_{2} \mathrm{O}\right]$ and $0.28 \mathrm{~g}$ of calcium acetate $\left[\mathrm{Ca}\left(\mathrm{CH}_{2} \mathrm{OOH}\right)_{2} \cdot \mathrm{H}_{2} \mathrm{O}\right]$ in $5 \mathrm{~mL}$ of deionized water. The $\mathrm{pH}$ of the solution was adjusted to $5.5 \mathrm{using}$ glacial acetic acid $\left[\mathrm{CH}_{3} \mathrm{COOH}\right]$. The solution was placed in a Parr bomb and heated at $100^{\circ} \mathrm{C}$ for 24 hours. The pale yellow precipitate was recovered from solution through centrifugation. The crystals were washed with four aliquots of boiling deionized water. The crystals were dried at room temperature until a constant weight was achieved.

\subsubsection{Acquisition of Natural Autunite}

Natural calcium meta-autunite $\mathrm{I}, \mathrm{Ca}\left[\left(\mathrm{UO}_{2}\right)\left(\mathrm{PO}_{4}\right)\right]_{2} \cdot 3 \mathrm{H}_{2} \mathrm{O}$, was obtained from northeastern Washington State. The material was previously characterized using ICP-OES and ICP-MS analyses, x-ray diffraction, and scanning electron microscopy to confirm the composition, structure, and morphology of the autunite minerals as $98-99 \%$ pure autunite with calculated anhydrous structural formula consistent with Caautunite: $\mathrm{Ca}\left[\left(\mathrm{UO}_{2}\right)\left(\mathrm{PO}_{4}\right)\right]_{2}$. Electron microprobe analyses further indicated that the autunite mineral contains $\sim 3$ waters of hydration per formula unit (p.f.u.) (Wellman et al. 2007a; Wellman et al. 2006a).

\subsection{Characterization of U(VI) Phases}

\subsubsection{X-Ray Diffraction}

$\mathrm{X}$-ray diffraction is a commonly used technique for identifying crystalline minerals that are $\geq 5 \%$ (by weight) of the bulk composition. Before mounting the samples, a representative sample of the bulk material was ground using an agate mortar and pestle to improve the diffraction patterns. X-ray diffraction data were obtained at $45 \mathrm{kV}$ and $40 \mathrm{~mA}$, using a Scintag ${ }^{\circledR}$ automated powder diffractometer (Model 3520). Tungsten-filtered copper radiation, $\mathrm{CuK}_{\alpha}=1.54 \AA$, was used to obtain diffraction patterns. The samples were analyzed over the 2-theta $(2 \theta)$ range from $2^{\circ}$ to $45^{\circ}$, using a step size of $0.04^{\circ}$, and a 2- second count time at each step.

\subsubsection{Scanning Electron Microscopy-Energy Dispersive Spectrometry}

Photomicrographs of pristine and post reaction solid phases were obtained by means of a scanning electron microscope JEOL 840 scanning electron microscope equipped with a Robinson 6.0 backscatter detector. The beam conditions were $20 \mathrm{KeV}$ acceleration and a $1 \mathrm{nA}$ beam current. The samples were mounted on an aluminum plate using double-sided tape and carbon-coated under a vacuum. The carbon coat provides a conductive path for the electrons and helps secure the particles. Images were acquired using GATAN DM software version 3.2, 1996.

An Oxford ISIS 300 series energy dispersive spectrometer (EDS) was used to determine chemical composition. EDS spectra were stored electronically using Oxford ISIS 300 version 3.2 software. An EDS spectrum represents the chemical composition of a particle found within a sample; while not all particles are counted for the same live/dead time period, a typical EDS spectrum is counted for $100 \mathrm{~s}$ with a 30\% dead time. 


\subsection{Solubility Testing of $\mathrm{U}(\mathrm{VI})$ Minerals}

Uranium will readily react with carbon dioxide to form stable uranyl-carbonate complexes. However, to quantify the solubility of uranium minerals under environmentally relevant conditions, and those representative of long-term storage conditions, all solubility experiments were done under ambient conditions. The solubility of soddyite, becquerelite, and uranophane were measured in simulated concrete porewater. Ewart et al. (1992) measured the elemental compositions of porewaters equilibrated with a series of Portland cement compositions: sulfate-resistant Portland cement (SRPC)/limestone (L), ordinary Portland cement (OPC)/blast furnace slag (BFS)/L, BFS/OPC, OPC/L, and Harwell. Based on these data, a series of synthetic cement leachates were prepared with $18 \mathrm{M} \Omega$ deionized water and reagentgrade chemicals from Aldrich Chemicals, namely calcium chloride $\left[\mathrm{CaCl}_{2} \cdot 2 \mathrm{H}_{2} \mathrm{O}\right]$, magnesium chloride $\left[\mathrm{MgCl}_{2} \cdot 6 \mathrm{H}_{2} \mathrm{O}\right]$, calcium sulfate $\left[\mathrm{CaSO}_{4}\right]$, sodium hydroxide $[\mathrm{NaOH}]$, calcium carbonate $\left[\mathrm{CaCO}_{3}\right]$, calcium hydroxide $\left[\mathrm{Ca}(\mathrm{OH})_{2}\right]$, silicic acid $\left[\mathrm{SiO}_{2} \bullet 2 \mathrm{H}_{2} \mathrm{O}\right]$, and aluminum nitrate $\left[\mathrm{Al}\left(\mathrm{NO}_{3}\right)_{3} \cdot 9 \mathrm{H}_{2} \mathrm{O}\right]$ (Table 8.1).

Table 8.1. Chemical Composition of Portland Cement-Equilibrated Waters ( From Ewart et al. 1992)

\begin{tabular}{lccccccccc}
\hline \multicolumn{1}{c}{ Cement } & $\mathrm{Ca}$ & $\mathrm{Na}$ & $\mathrm{Mg}$ & $\mathrm{Cl}$ & $\mathrm{SO}_{4}{ }^{2-}$ & $\mathrm{CO}_{3}{ }^{2-}$ & $\mathrm{Al}$ & $\mathrm{Si}$ & $\mathrm{pH}$ \\
\hline SRPC/L & $6.7 \mathrm{E}-3$ & $2 \mathrm{E}-4$ & $<8 \mathrm{E}-8$ & $4 \mathrm{E}-5$ & $4 \mathrm{E}-5$ & $8.5 \mathrm{E}-5$ & $7.4 \mathrm{E}-4$ & $5.3 \mathrm{E}-6$ & 12.5 \\
9:1 BFS/OPC & $6.8 \mathrm{E}-3$ & $3.4 \mathrm{E}-3$ & $4.7 \mathrm{E}-7$ & $6.2 \mathrm{E}-5$ & & $1 \mathrm{E}-4$ & $8 \mathrm{E}-5$ & $2.3 \mathrm{E}-5$ & 12.2 \\
OPC/BFS/L & $6.7 \mathrm{E}-3$ & $5 \mathrm{E}-3$ & $<8 \mathrm{E}-7$ & $2.4 \mathrm{E}-3$ & $6 \mathrm{E}-3$ & $2.8 \mathrm{E}-4$ & $9.5 \mathrm{E}-5$ & $7 \mathrm{E}-4$ & 12.1 \\
OPC/L & $2 \mathrm{E}-2$ & $8.3 \mathrm{E}-4$ & $<4 \mathrm{E}-8$ & $9 \mathrm{E}-5$ & $1 \mathrm{E}-5$ & $2 \mathrm{E}-5$ & $1 \mathrm{E}-5$ & & 12 \\
HARWELL & $1 \mathrm{E}-2$ & $5 \mathrm{E}-5$ & $5 \mathrm{E}-6$ & $2 \mathrm{E}-3$ & $3 \mathrm{E}-3$ & $3 \mathrm{E}-5$ & & & 12 \\
\hline
\end{tabular}

The solubility of becquerelite, soddyite, uranophane, and autunite in the synthetic porewater solutions were measured over a period of 4 months. Approximately $0.25 \mathrm{~g}$ of the respective uranium phase was added to polypropylene tubes containing $20 \mathrm{~mL}$ of the respective porewater solution. The tubes were sealed and shaken for predetermined sample intervals of 1, 7, 14, 21, 28, 42, 56, 70, 84, 98, and 112 days. A set of duplicate tubes were started for each sampling interval to prevent volume changes that could impact saturation indices over the duration of the experiment. The suspensions were centrifuged and the supernatant was filtered through $0.45-\mu \mathrm{m}$ filters. The filtrate was analyzed for silicon and calcium using ICP-OES and for uranium using ICP-MS. Selected samples of equilibrated solids were taken for x-ray diffraction (XRD) and scanning electron microscopy (SEM) to compare the structure of the materials during reaction and identify the formation of secondary phases.

\subsection{Results and Discussion}

\subsubsection{Characterization of U(VI) Phases}

Figure 8.1 displays the XRD patterns for synthetic becquerelite,soddyite, and uranophane. X-ray diffraction patterns for becquerelite, soddyite, and uranophane are consistent with published spectra. 

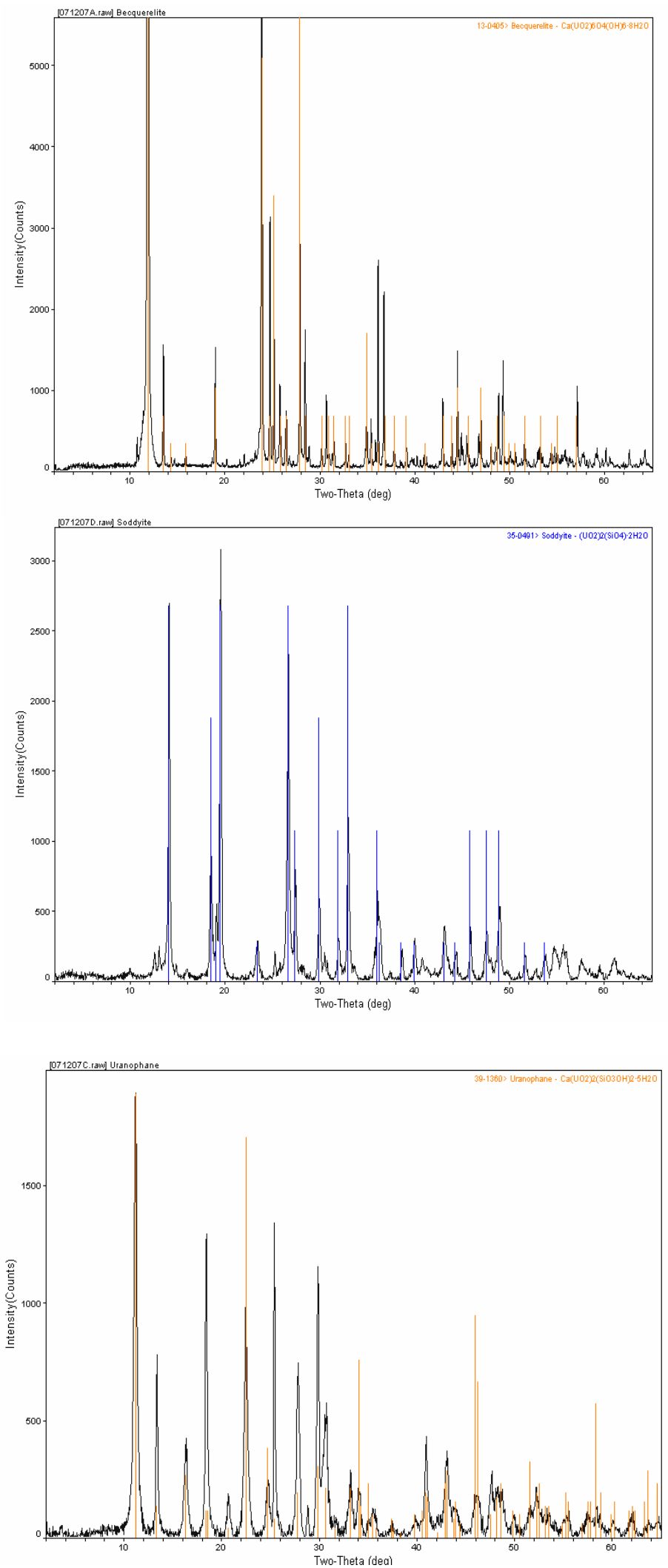

Figure 8.1. X-ray Diffraction Pattern for Becquerelite (top), Soddyite (middle), and Uranophane (bottom) 
Becquerelite crystals lie in the orthorhombic-pyramidal space group Pn21a. Scanning electron photomicrographs of becquerlite (Error! Reference source not found., middle) illustrate the rhombohedral, tabular crystals. Soddyite crystals lie in the orthorhombic-dipyramidal space group F ddd. Scanning electron photomicrographs of soddyite (Error! Reference source not found., left) illustrate the blocky, tabular crystals. Uranophane crystals lie in the monoclinic-sphenoidal space group P2 ${ }_{1}$. Scanning electron photomicrographs of uranophane (Error! Reference source not found., right) illustrate the acicular, fibrous fine-grained crystal tuffs.

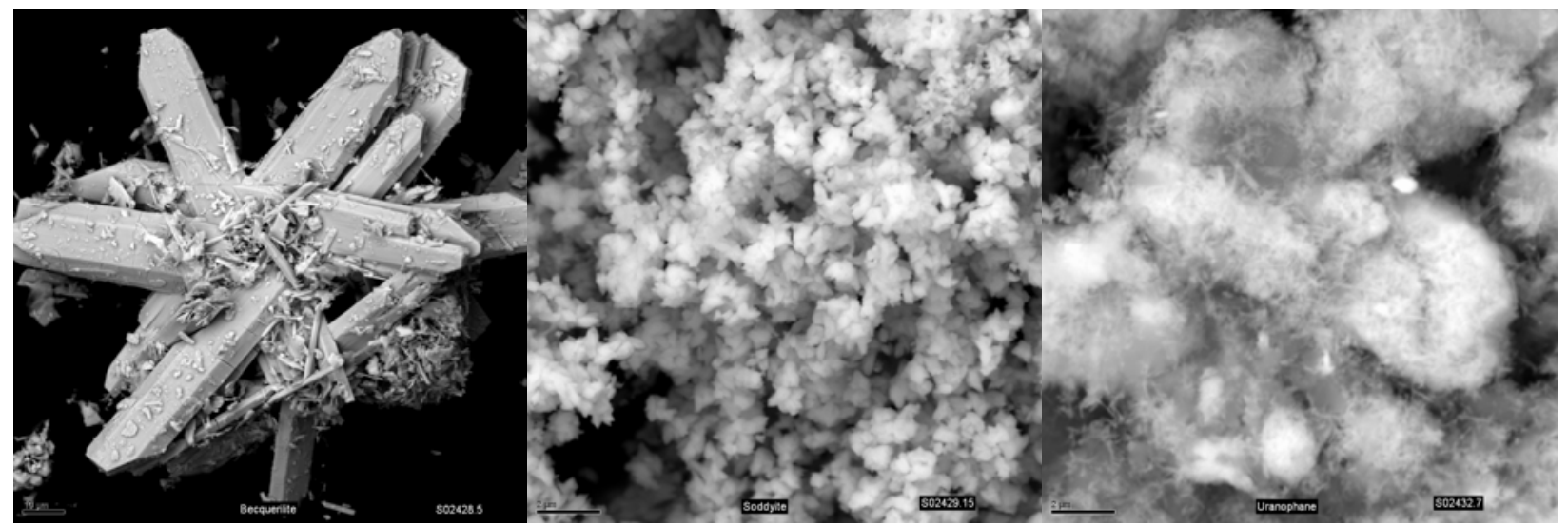

Figure 8.2. Scanning Electron Photomicrographs of Becquerelite, Soddyite, and Uranophane (left to right).

\subsubsection{Solubility Testing of U(VI) Minerals}

\subsubsection{Becquerelite, $\mathrm{Ca}\left(\mathrm{UO}_{2}\right)_{6} \mathrm{O}_{4}\left(\mathrm{OH}_{6}\right)\left(\mathrm{H}_{2} \mathrm{O}\right)_{8}$}

The aqueous concentration of uranium obtained for becquerlite in the simulated Portland cementequilibrated porewaters are represented in Figure 8.3 in the form of $\log _{10}[\mathrm{U}(\mathrm{VI})]_{\mathrm{aq}}$ (molality) versus time. The aqueous concentrations of uranium reached steady-state within 100 days in all simulated porewaters, except 9:1 BFS/OPC. The aqueous concentration of uranium in the 9:1 BFS/OPC porewater deviated widely throughout the duration of testing. Test periods longer than those presented here are necessary to reach steady-state for becquerlite in 9:1 BFS/OPC porewaters. The aqueous, equilibrium uranium concentration increases in the respective porewaters in the following order: $\mathrm{OPC} / \mathrm{L}<$ Harwell $\approx$ $\mathrm{SRPC} / \mathrm{L}<\mathrm{OPC} / \mathrm{BFS} / \mathrm{L}$. The increase in aqueous uranium concentrations is correlated with decreasing concentration of calcium in the simulated porewater. Additionally, porewater 9:1 BFS/OPC contains the highest concentration of carbonate.

The SEM analyses do not suggest the formation of secondary phases in 9:1 BFS/OPC, OPC/L, $\mathrm{OPC} / \mathrm{BFS} / \mathrm{L}$, or SRPC/L porewaters. In the Harwell porewater, however, the formation of a secondary precipitate, which did not possess a well-defined morphology, was observed on the surface of some becquerelite crystals (Figure 8.4). The EDS analyses indicated this was a mixed calcium-sodium-uranium phase that was composed of $1.45 \mathrm{wt} \%$ sodium, $2.66 \mathrm{wt} \%$ calcium, and $54.99-92.36 \mathrm{wt} \%$ uranium. This phase is poorly crystalline mixed sodium- and calcium- oxyhydroxide. Complete anion and cation analyses coupled with geochemical modeling of aqueous solutions will further elucidate the formation and identity of secondary uranium phases in Harwell porewater. 


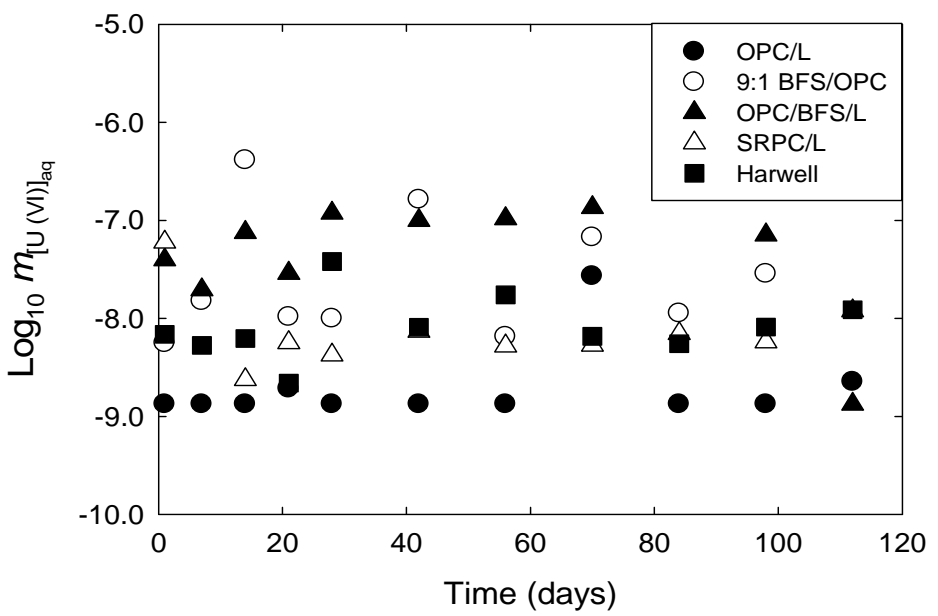

Figure 8.3. Solubility of Becquerlite in Simulated Portland Cement-Equilibrated Waters.

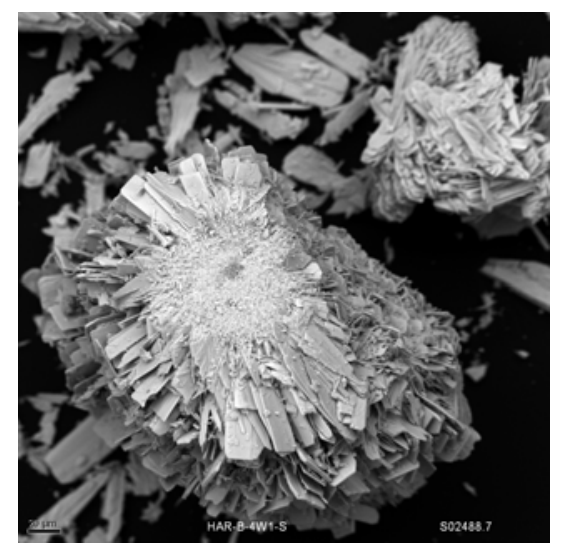

Figure 8.4. Scanning-Electron Photomicrographs of Solids Material from the Reaction of Becquerlite in Harwell Porewater Displaying the Formation of Poorly Crystalline, Mixed Sodium- and Calcium-Oxyhydroxide Phase on the Surface of Becquerlite Crystals.

Results presented here suggest that becquerlite attains equilibrium conditions rapidly within concrete porewaters. There was no observed effect of carbonate or sulfate within the porewaters on the stability of becquerlite, or the formation of secondary phases. The becquerelite will persist within concrete waste forms as a long-term control on uranium.

\subsubsection{Soddyite, $\left(\mathrm{UO}_{2}\right)_{2} \mathrm{SiO}_{4}\left(\mathrm{H}_{2} \mathrm{O}\right)_{2}$}

The aqueous concentrations of uranium obtained for soddyite in the simulated Portland cementequilibrated porewaters are represented in Figure 8.5 in the form or $\log _{10}[\mathrm{U}(\mathrm{VI})]_{\mathrm{aq}}$ (molality) versus time. The aqueous concentration of uranium reached steady-state within 100 days in all simulated porewaters, except Harwell. The aqueous concentration of uranium in the Harwell solution appeared to reach steadystate at $\sim 10$ days. However, at 70 days the aqueous concentration of uranium began to increase. Test periods longer than those presented here are necessary to reach steady-state for soddyite in Harwell porewaters. Moreover, the rate at which equilibrium is reached in the other porewaters differs depending on the porewater composition. Equilibrium is rapidly attained within $\leq 50$ days for soddyite in BFS and 9:1 BFS/OPC. Longer time frames, 60 to 100 days, are required to reach equilibrium in SRPC/L and 
$\mathrm{OPC} / \mathrm{L}$ porewaters. The aqueous, equilibrium uranium concentration increases in the respective porewaters in the following order: of Harwell $<$ OPC $/ \mathrm{L}<\mathrm{OPC} / \mathrm{BFS} / \mathrm{L}<9: 1 \mathrm{BFS} / \mathrm{OPC}=\mathrm{SPRC} / \mathrm{L}$. Comparable to aqueous uranium concentrations measured from solubility tests conducted with becquerlite, the increase in aqueous uranium concentrations is correlated with decreasing concentration of calcium in the simulated porewater. Moreover, the increase in aqueous uranium concentration in OPC/BFS/L, 9:1 BFS/OPC, SPRC/L exhibits a relationship with increasing concentration of aqueous silicon.

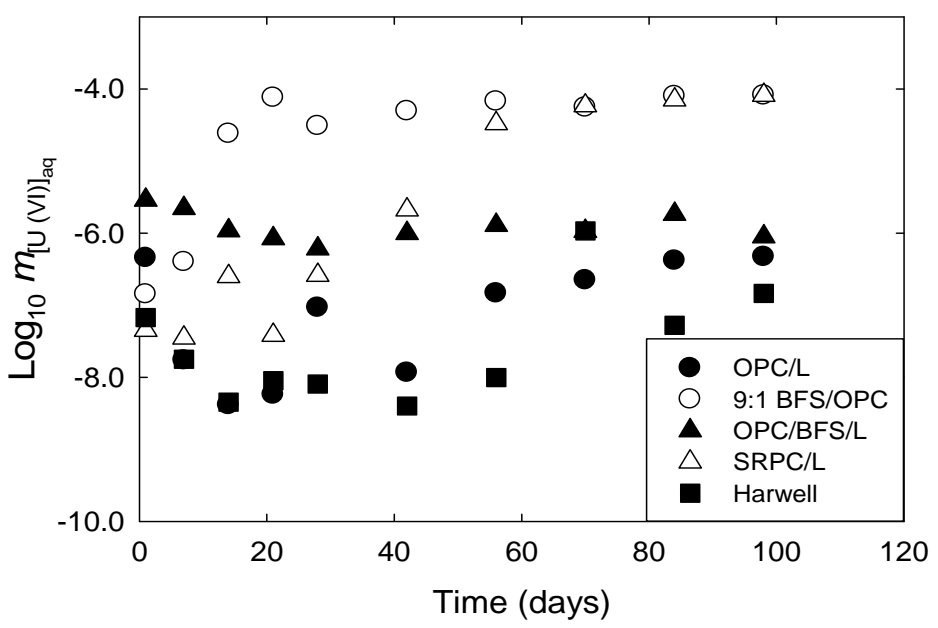

Figure 8.5. Solubility of Soddyite in Simulated Portland Cement-Equilibrated Waters

The SEM of soddyite in BFS and 9:1 BFS/OPC at 100 days does not reveal the formation of any secondary phases. XRD results confirming that there was no change in mineralogy during solubility testing is pending. The SEM analysis of soddyite in Harwell porewaters reveals a morphologically different phase is present as a minor component of the solid phase (Figure 8.6). Analysis using EDS indicates the phase is a calcium-bearing uranium-silicate containing 1.43-2.01 wt $\% \mathrm{Ca}, 4.55-5.62 \mathrm{wt} \%$ $\mathrm{Si}, 47.83-62.99 \mathrm{wt} \% \mathrm{U}$, and $29.40-44.04 \mathrm{wt} \% \mathrm{O}$. The morphology is suggestive of uranophane; however the chemical composition is not strictly consistent with any one calcium-uranium-silicate phase. Further investigation is necessary to discern the identity of this phase. The formation of a minor inclusion of acicular, fibrous fine-grained crystal tuffs, comparable to the results in Harwell, were also observed in OPC/BFS/L, 9:1 BFS/OPC, SRPC/L porewaters; no additional secondary phases were observed.

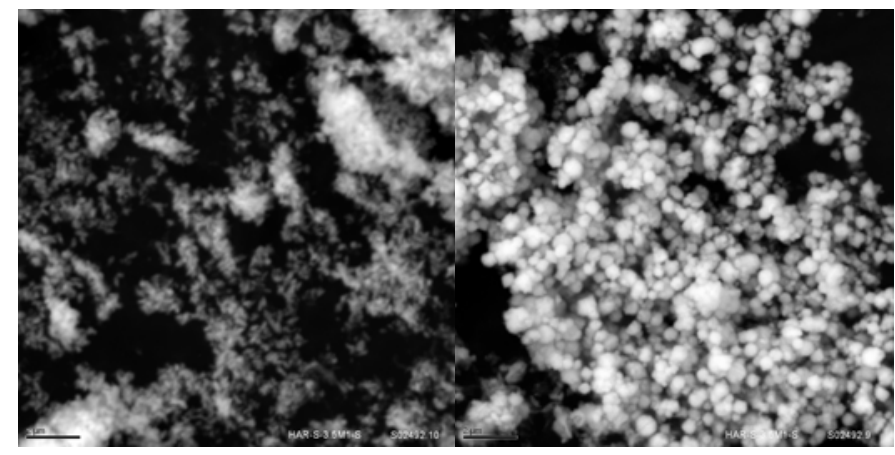

Figure 8.6. Scanning-Electron Photomicrographs of Solids Material from the Reaction of Soddyite in Harwell Porewater. The image on the right shows the persistence of soddyite; the image on the left displays the formation of acicular, fibrous fine-grained crystal tuffs. 
Similar results were observed from SEM images of reacted solid phases extracted from the reaction of soddyite in $\mathrm{OPC} / \mathrm{L}$. However, the higher concentration of calcium present in $\mathrm{OPC} / \mathrm{L}$ relative to the Harwell solution resulted in substantial formation of calcium-bearing, fibrous fine-grained tuffs; additionally, the formation acicular, fibrous coarse-grained crystal tuffs also was observed (Figure 8.7). Analysis by EDS indicates that the phase is a sodium-bearing uranium-silicate containing $3.27 \mathrm{wt} \% \mathrm{Na}$, $6.29 \mathrm{wt} \% \mathrm{Si}, 51.33 \mathrm{wt} \% \mathrm{U}$, and $39.11 \mathrm{wt} \% \mathrm{O}$. The morphology is consistent with sodium-boltwoodite, a uranophane-group mineral. Further confirmation of the chemical composition is necessary to confirm the presence of sodium boltwoodite. Complete anion and cation analyses coupled with geochemical modeling of aqueous solutions will further elucidate the formation and identity of secondary uranium phases.

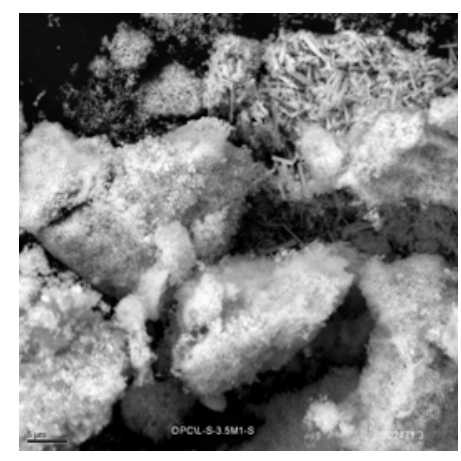

Figure 8.7. Scanning-Electron Photomicrographs of Solids Material from the Reaction of Soddyite in OPC/L Porewater Displaying the Formation of Acicular, Fibrous Coarse-Grained Tuffs

\subsubsection{Uranophane, $\mathrm{Ca}\left(\mathrm{UO}_{2}\right)_{2}\left(\mathrm{SiO}_{3} \mathrm{OH}\right)_{2}\left(\mathrm{H}_{2} \mathrm{O}\right)_{5}$}

The aqueous concentrations of uranium obtained for uranophane in the simulated Portland cementequilibrated porewaters are represented in Figure 8.8 in the form of $\log _{10}[\mathrm{U}(\mathrm{VI})]_{\mathrm{aq}}$ (molality) versus time. The aqueous concentration of uranium reached steady-state within 100 days in all simulated porewaters. Additionally, the rate at which equilibrium was reached is relatively consistent and does not depend on the porewater composition. Equilibrium is rapidly attained within $\leq 30$ days. The aqueous, equilibrium uranium concentration increases in the respective porewaters in the following order: Harwell $\approx \mathrm{OPC} / \mathrm{L}<$ 9:1 BFS/OPC $<\mathrm{SPRC} / \mathrm{L}<\mathrm{OPC} / \mathrm{BFS} / \mathrm{L}$. As observed with becquerlite and soddyite, the increase in aqueous uranium concentrations is correlated with decreasing concentration of calcium in the simulated porewater. There was no clear correlation with any other aqueous ligands.

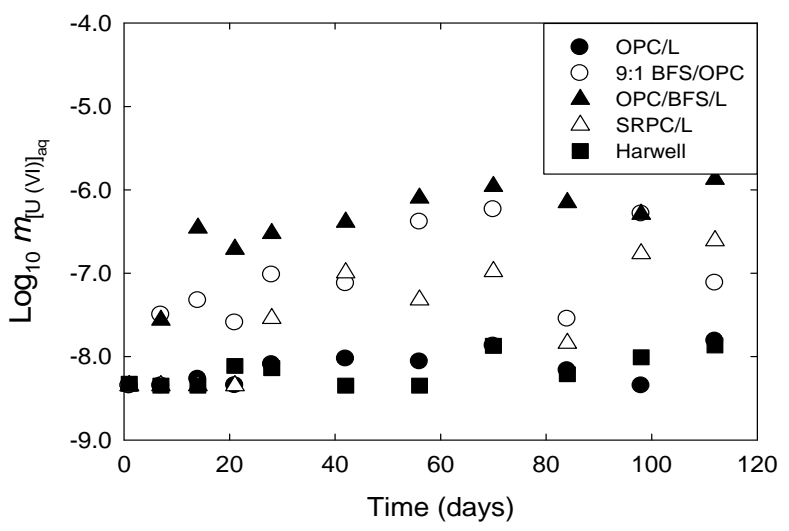

Figure 8.8. Solubility of Uranophane in Simulated Portland Cement-Equilibrated Waters. 


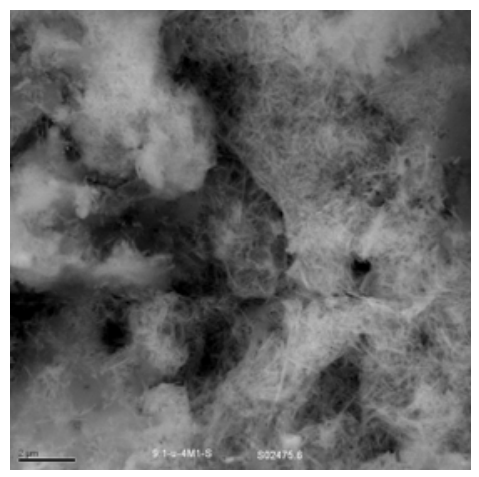

Figure 8.9. Scanning-Electron Photomicrographs of Solids Material from the Reaction of Uranophane in 9:1 BFS/OPC Porewater Displaying the Formation of Acicular, Fibrous Fine-Grained Crystal Tuffs

No secondary phases were identified in any of the other porewaters. The morphology of all reacted solid phases was the acicular, fibrous fine-grained tuffs consistent with the unreacted uranophane (Figure 8.9). Further, the lack of secondary phases supports the possibility that the acicular, fibrous finegrained tuff phase present in the soddyite post-reaction solids (discussed above) is a uranophane group phase.

\subsubsection{Autunite, $\mathrm{Ca}\left(\mathrm{UO}_{2}\right)_{2}\left(\mathrm{PO}_{4}\right)_{2}\left(\mathrm{H}_{2} \mathrm{O}\right)_{12}$}

The aqueous concentrations of uranium obtained for autunite in the simulated Portland cementequilibrated porewaters are represented in Figure 8.10 in the form of $\log _{10}[\mathrm{U}(\mathrm{VI})]_{\mathrm{aq}}$ (molality) versus time. The aqueous concentration of uranium reached steady-state within 100 days in all simulated porewaters, except OPC/L and SRPC/L. The aqueous concentration of uranium in the OPC/L and $\mathrm{SRPC} / \mathrm{L}$ porewaters deviated widely throughout the duration of testing. Test periods longer than those presented here are necessary to reach steady-state for autunite in OPC/L and SRPC/L porewaters. The aqueous, equilibrium uranium concentration increases in the respective porewaters in the following order: Harwell $<$ OPC/BFS/L $<$ 9:1 BFS/OPC. As observed with other uranium (VI) minerals, the increase in aqueous uranium concentrations is correlated with the decrease in the concentration of calcium in the simulated porewater. There was no clear correlation with any other aqueous ligands.

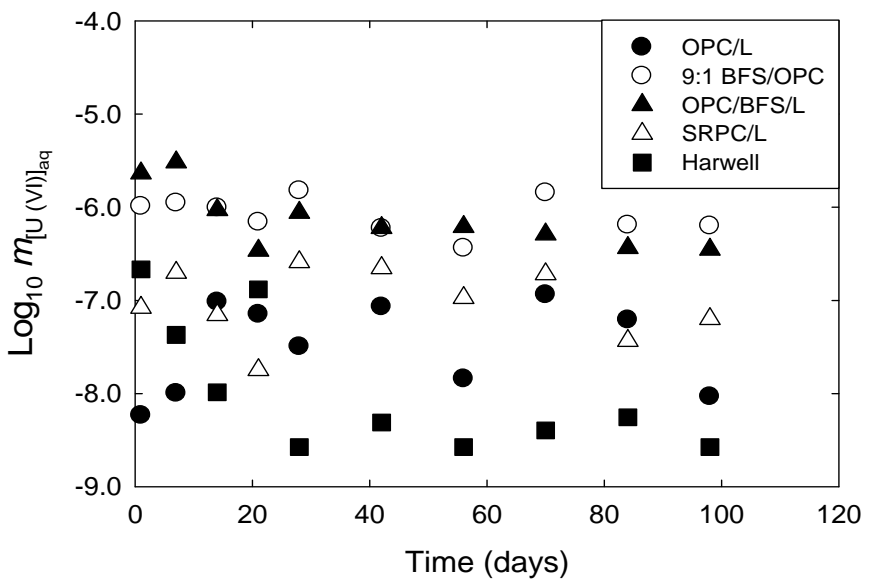

Figure 8.10. Solubility of Autunite in Simulated Portland Cement-Equilibrated Waters 
The SEM analyses do not suggest the formation of secondary phases in 9:1 BFS/OPC, OPC/L, Harwell, or SRPC/L porewaters. The formation of secondary phases was observed in the OPC/BFS/L porewater (Figure 8.11). Analysis using EDS indicates the spherical phase is a mixed sodium-calciumbearing uranium-phosphate containing $1.22 \mathrm{wt} \% \mathrm{Na}, 16.57 \mathrm{wt} \% \mathrm{Ca}, 10.10 \mathrm{wt} \% \mathrm{P}, 16.15 \mathrm{wt} \% \mathrm{U}$, and $55.97 \mathrm{wt} \% \mathrm{O}$. The rod-like phase is a mixed sodium-calcium-bearing uranium-phosphate containing 1.31 $\mathrm{wt} \% \mathrm{Na}, 14.34 \mathrm{wt} \% \mathrm{Ca}, 8.30 \mathrm{wt} \% \mathrm{P}, 28.02 \mathrm{wt} \% \mathrm{U}$, and $46.26 \mathrm{wt} \% \mathrm{O}$. Complete anion and cation analyses coupled with geochemical modeling of aqueous solutions will further elucidate the formation and identity of secondary uranium phases.

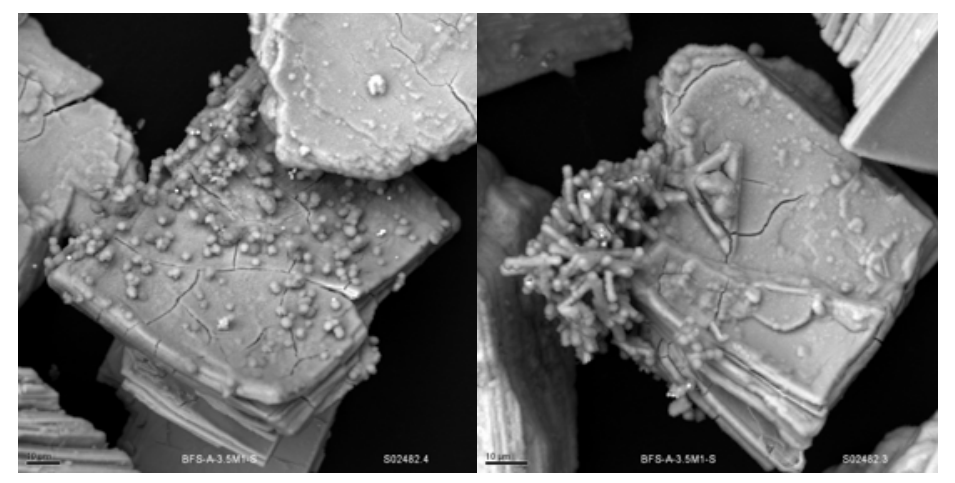

Figure 8.11. Scanning-Electron Photomicrographs of Solids Material from the Reaction of Autunite in OPC/BFS/L Porewater. Photo on the left displays the formation of spherical secondary precipitates; photo on the right indicates the formation of a rod-like secondary phase.

\subsubsection{Discussion and Conclusions}

Precipitation of uranyl minerals follows the thermodynamic progression of precipitating those which have the lowest solubilities, for which precipitation kinetics do not present significant barriers to nucleation, followed by precipitation of the advanced uranium minerals that occurs over a considerable time frame (Finch et al. 1999; Smith 1984). The general sequence begins with the uranyl-hydroxides, followed by the -carbonate, -silicates and finally, the highly stable uranyl-phosphates. Therefore, it was hypothesized that the measured solubility of the uranyl-oxyhydroxide (becquerlite), uranyl-silicates (soddyite and uranophane), and uranyl-phosphate (autunite) tested here would decrease accordingly. However, the aqueous concentration of uranium released from all uranyl phases in the simulated Portland cement-equilibrate porewaters ranged from $\log _{10}[\mathrm{U}(\mathrm{VI})]_{\mathrm{aq}}=-5$ to -9 , suggesting that porewater cations and anions may be influencing the solubility of uranium through complexation. The significance of porewater cation and anions on the uranium mineral solubility is also suggested by the formation of secondary phases.

Complexation of aqueous uranium can increase the solubility of uranium minerals (Langmuir 1997b, a). Two mechanisms may contribute to the increase in aqueous uranium: 1) a chelating effect, whereby oxygen-containing ligands (i.e., carbonate, phosphate, and hydroxide) bind to uranium in the mineral structure and subsequently release uranium complexes into solution, or 2) release of uranium from the mineral structure is followed by complexation by aqueous ligand. The latter would, thereby, reduce the activity of uranium in solution allowing further release of uranium from the mineral structure. The composition of the porewaters contains numerous ligands that form stable complexes with uranyl in solution and can significantly increase the aqueous concentration of uranium. Uranyl cations will form strong complexes with hydroxide (Cordfunke 1964, 1969; Grenthe et al. 1992; Langmuir 1978, 1997b), 
carbonate (Langmuir 1978; Clark et al. 1995); sulfate (Langmuir 1978, 1997b), silicate (Cordfunke 1964, 1969; Grenthe et al. 1992; Langmuir 1978, 1997b), and phosphate (Sandino and Bruno 1992; Langmuir 1978, 1997b; Grenthe et al. 1992).

System $\mathrm{pH}$ can strongly influence the solubility, hydrolysis, sorption, complexation, and colloid formation of uranium. Hydrolysis reactions are highly sensitive to the activity and concentration of hydrogen ions in solution (Cordfunke 1969; Langmuir 1978; Baes and Schreyer 1953; Sylva and Davidson 1979). For example, Figure 8.12 is a chart, generated using MINTEQA2, displaying uranium speciation at $25^{\circ} \mathrm{C}$ in the absence of all ligands except hydroxide. The plot shows that stepwise monomeric species dominate the distribution of uranium across the $\mathrm{pH}$ range.

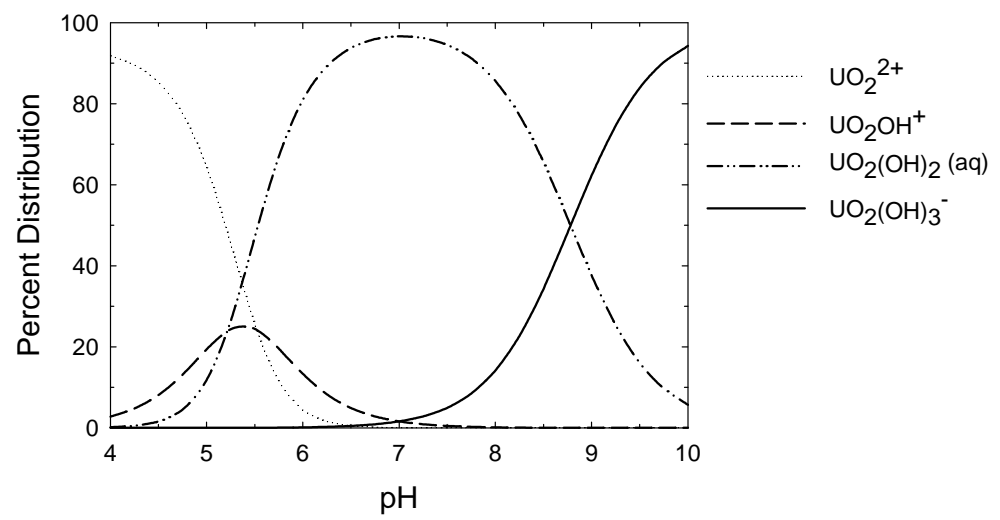

Figure 8.12. Percent Distribution of $\mathrm{U}^{6+}-\mathrm{H}_{2} \mathrm{O}$ System at $25^{\circ} \mathrm{C}, \mathrm{I}=0.1 \mathrm{M}, \mathrm{P}_{\mathrm{CO} 2}=0$ bar and $\Sigma \mathrm{U}^{6+}=10^{-6} \mathrm{M}$ in the Absence of Complexing Ligands Other than Hydroxide

Figure 8.13 demonstrates the significance of $\mathrm{pH}$ and ligand identity on the speciation of uranium. The extent to which carbonate competes for uranium over hydroxyl complexes, especially above $\mathrm{pH} 6$, is evident. Uranyl-carbonate species are very significant in the uranium geochemical cycle. They increase the solubility of uranium minerals, facilitate uranium (IV) oxidation, and because these species are anionic in nature, they limit the extent of sorption in oxidized waters, thereby increasing the mobility of uranium (Langmuir 1997b, a).

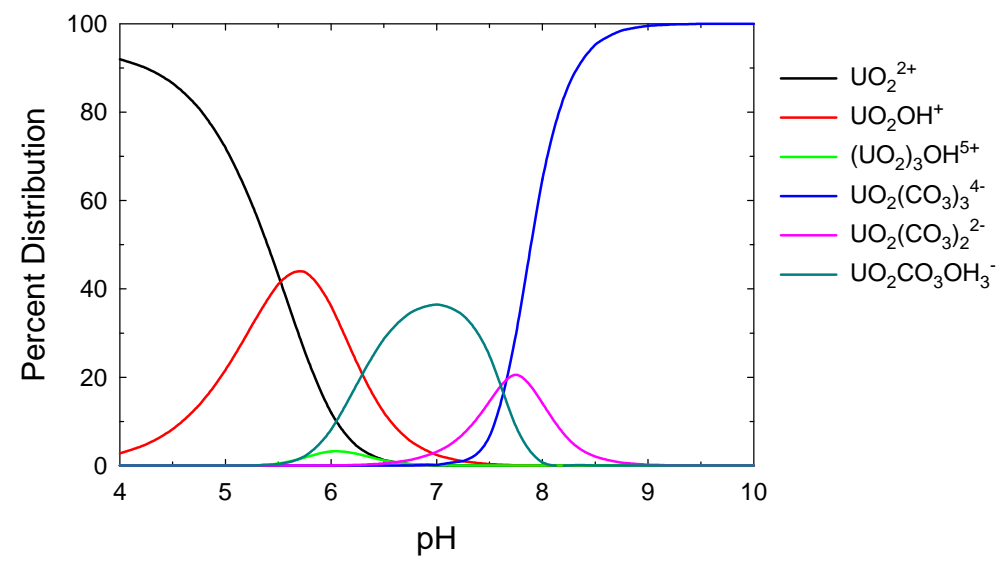

Figure 8.13. Percent Distribution of $\mathrm{U}^{6+}$ Species Calculated Using MINTEQA2 at $25^{\circ} \mathrm{C}, \mathrm{I}=0.1 \mathrm{M}$, and $\mathrm{pCO}_{2}=10^{-3.5}$ bar for $\sum \mathrm{U}^{6+}=10^{-6} \mathrm{M}$ 
Uranyl-sulfate complexes are important in aqueous environments where $\mathrm{pH}<6$, the evaporation rate is high, sulfides are being oxidized, and carbonate is absent (Ondrus et al. 2003; Garrels and Christ 1965). There are few aqueous uranyl-silicate complexes which are moderately insoluble and readily precipitate to form uranyl-silicate minerals. As such, uranyl-silicate minerals are of relatively low solubility and do not rapidly dissolve on exposure to fresh water. In the $\mathrm{pH}$ range of 6-9, phosphate complexes dominant the system when $[\mathrm{PO} 4] /[\mathrm{CO} 3]>0.1$. Uranyl forms more stable complexes with phosphate than with any other ligand (Langmuir 1978). Figure 8.14 illustrates the significance of the ligand species and concentration in determining the dominate uranium species at a given $\mathrm{pH}$ value.

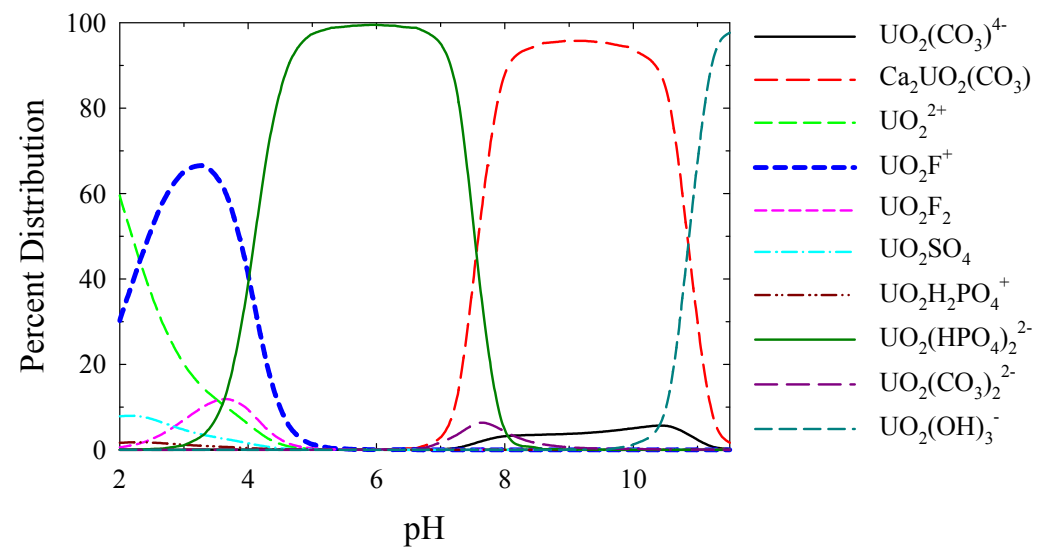

Figure 8.14. Percent Distribution of $\mathrm{U}^{6+}$ Aqueous Species Calculated Using MINTEQA2 in Hanford Groundwater Well-699-S3-25.

There was no observed effect of carbonate or sulfate within the porewaters on the stability of the uranyl minerals, or on the formation of secondary phases. However, there was a clear effect of calcium and silicon in the porewaters on the stability of all uranium minerals, as well as on the formation of secondary phases. Although confirmation of secondary phases is still necessary, preliminary results suggest the formation of 1) a calcium-uranium oxide from the reaction of becquerlite, 2) uranophane group minerals from the reaction of soddyite, and 3) mixed sodium-calcium uranium phosphate secondary phases from the reaction of autunite in simulated Portland cement-equilibrated porewater. Completion of analytical analyses to quantify aqueous cations and anions, coupled with geochemical thermodynamic modeling will aid in further understanding the stability and long-term control of uranium provided by concrete waste forms. However, it is suggested here that 1) the release of uranium from the degradation of uranium oxyhydroxides will be controlled by the formation of secondary uranium oxides; 2) regardless of the replacement of soddyite by uranophane, uranyl-silicate phases will persist within concrete waste forms; and 3) the release of uranium from the degradation of uranium-phosphate phases will be controlled by the formation of secondary uranyl-phosphate phases. 


\subsection{References}

Baes CF, and JM Schreyer. 1953. The Chemistry of Uranium (VI) Orthophosphate Solutions: Part III, the Solubility Behavior of $\mathrm{UO}_{2} \mathrm{HPO}_{4} * 4 \mathrm{H}_{2} \mathrm{O}$ in Perchloric Acid Solutions, ORNL-1579, Oak Ridge National Laboratory, Oak Ridge.

Casas I, I Perez, ME Torrero, J Bruno, E Cera, and L Duro. 1997. Dissolution Studies of Synthetic Soddyite and Uranophane, 97-15,

Clark DL, DE Hobart, and MP Neu. 1995. "Actinide Carbonate Complexes and Their Importance in Actinide Environmental Chemistry." Chemical Reviews 95:25 - 48.

Cordfunke EHP. 1964. "Heats of Formation of Some Hexavalent Uranium Compounds." Journal of Physical Chemistry 68(11):3353-3356.

Cordfunke EHP. 1969. The Chemistry of Uranium. Elsevier Publishing Company, Amsterdam, The Netherlands.

Ewart FT, JL Smith-Briggs, HP Thonason, and SJ Williams. 1992. "The Solubility of Actinides in a Cementitious near-Field Environment." Waste Management 12:241-252.

Garrels RM, and CL Christ. 1965. Solutions, Minerals and Equilibria. Harper and Row Publ. Co., New York.

Grenthe I, J Fuger, RJM Konings, RJ Lemire, AB Muller, C Nguyen-Trung, and H Wanner. 1992. Chemical Thermodynamics of Uranium. OECD Nuclear Energy Agency, Amsterdam.

Langmuir D. 1978. "Uranium Solution-Mineral Equilibria at Low Temperatures with Applications to Sedimentary Ore Deposits." Geochimica et Cosmochimica Acta 42:547-569.

Langmuir D. 1997a. Aqueous Environmental Chemistry. Prentice-Hall, Upper Saddle River, NJ.

Langmuir D. 1997b. "Aqueous Geochemistry of Uranium." In: Aqueous Environmental Chemistry. R McConnin, Ed., Prentice-Hall, Upper Saddle River: 494 - 512.

Mann FM, RJ Puigh II, SH Finfrock, EJ Freeman, R Khaleel, DH Bacon, MP Bergeron, PB McGrail, and SK Wurstner. 2001. Hanford Immobilized Low-Activity Waste Performance Assessment: 2001 Version, DOE/ORP-2000-24, Rev. B. Pacific Northwest National Laboratory, Richland, WA.

Maset ER, SH Sidhu, A Fisher, A Heydon, PJ Worsfold, AJ Cartwright, and MJ Keith-Roach. 2006. "Effect of Organic Co-Contaminants on Technetium and Rhenium Speciation and Solubility under Reducing Conditions." Environmental Science and Technology 40(17):5472-5477.

Mattigod SV, GA Whyatt, RJ Serne, PF Martin, KE Schwab, and MI Wood. 2001. Diffusion and Leaching of Selected Radionuclides (Iodine-129, Technetium-99, and Uranium) through Category 3 Waste Encasement Concrete and Soil Fill Material, PNNL-13639. Pacific Northwest National Laboratory, Richland, WA. 
Nguyen SN, RJ Silva, HC Weed, and JE Andrews. 1992. "Standard Gibbs Free Energies of Formation at the Temperature 303.15k of Four Uranyl Silicates: Soddyite, Uranophane, Sodium Boltwoodite, and Sodium Weeksite." Journal of Chemical Thermodynamics 25:359-376.

Ondrus P, R Skala, F Veselovsky, J Sejkora, and C Vitti. 2003. "Cejkaite, the Triclinic Polymorph of $\mathrm{Na}_{4}\left(\mathrm{UO}_{2}\right)\left(\mathrm{CO}_{3}\right)_{3}$ - a New Mineral from Jachymov Czech Republic." American Mineralogist 88:686-693.

Sandino A, and J Bruno. 1992. "The Solubility of $\left(\mathrm{UO}_{2}\right)_{3}\left(\mathrm{PO}_{4}\right)_{2} 4 \mathrm{H}_{2} \mathrm{O}(\mathrm{s})$ and the Formation of U (Vi) Phosphate Complexes: Their Influence Speciation in Natural Waters." Geochimica et Cosmochimica Acta 56:4135-4145.

Serne RJ, JL Conca, VL LeGore, KJ Cantrell, CW Lindenmeier, JA Campbell, JE Amonette, and MI Wood. 1993. Solid-Waste Leach Characterization and Contaminant-Sediment Interactions, PNL-8889, Vol. 1. Pacific Northwest Laboratory, Richland, WA.

Serne RJ, RO Lokken, and LJ Criscenti. 1992. "Characterization of Grouted LLW to Support Performance Assessment." Waste Management 12:271-287.

Serne RJ, WJ Martin, and VL LeGore. 1995. Leach Test of Cladding Removal Waste Grout Using Hanford Groundwater, PNL-10745. Pacific Northwest Laboratory, Richland, WA.

Serne RJ, WJ Martin, VL LeGore, CW Lindenmeier, SB McLaurine, PFC Martin, and RO Lokken. 1989. Leach Tests on Grouts Made with Actual and Trace Metal-Spiked Synthetic Phosphate/Sulfate Waste., PNL-7121. Pacific Northwest Laboratory, Richland, WA.

Sylva RN, and MR Davidson. 1979. "The Hydrolysis of Metal Ions. Part 2. Dioxouranium (VI)." Dalton Transactions 8:465-471.

Wellman DM, SV Mattigod, GA Whyatt, L Powers, KE Parker, LN Clayton, and MI Wood. 2006. Diffusion of Iodine and Rhenium in Category 3 Waste Encasement Concrete and Soil Fill Material, PNNL-16268. Pacific Northwest National Laboratory, Richland, WA.

Wellman DM, KM Gunderson, JI Icenhower, and SW Forrester. 2007a. "Dissolution Kinetics of Synthetic and Natural Meta-Autunite Minerals, $\mathrm{X}_{3-\mathrm{N}}{ }^{\mathrm{n}+}\left[\left(\mathrm{UO}_{2}\right)\left(\mathrm{PO}_{4}\right)\right]_{2} \quad \mathrm{XH}_{2} \mathrm{O}$, under Acidic Conditions." Geochemistry Geophysics Geosystems 8(Q11001):1-16.

Wellman DM, JP Icenhower, AP Gamerdinger, and SW Forrester. 2006a. "Effects of pH, Temperature, and Aqueous Organic Material on the Dissolution Kinetics of Meta-Autunite Minerals, $(\mathrm{Na}, \mathrm{Ca})_{2-1}\left[\left(\mathrm{UO}_{2}\right)\left(\mathrm{PO}_{4}\right)\right]_{2}$ 3 $\mathrm{H}_{2} \mathrm{O}$." American Mineralogist 91:143-158.

Wellman DM, SV Mattigod, L Powers, KE Parker, LN Clayton, and MI Wood. 2007b. Concrete Property and Radionuclide Migration Tests, PNNL-17676, Pacific Northwest National Laboratory, Richland, WA.

Wood MI, R Khaleel, PD Rittman, AH Lu, S Finfrock, RJ Serne, and KJ Cantrell. 1995. Performance Assessment for the Disposal of Low-Level Waste in the 218-W-5 Burial Ground, WHC-EP-0645. Westinghouse Hanford Company, Richland, WA. 


\section{Distribution}

No. of

Copies

\# Name

Organization

Address

City, State and ZIP Code

\# Organization

Address

City, State and ZIP Code Name

Name

Name

Name

Name (\#)

\# Name

Organization

Address

City, State and ZIP Code
No. of

Copies

\# Foreign Distribution

\# Name

Organization

Address

Address line 2

COUNTRY

\# Local Distribution

Pacific Northwest National Laboratory

Name

Name

Name

Name

Name
Mailstop

Mailstop

Mailstop

Mailstop

(PDF) 


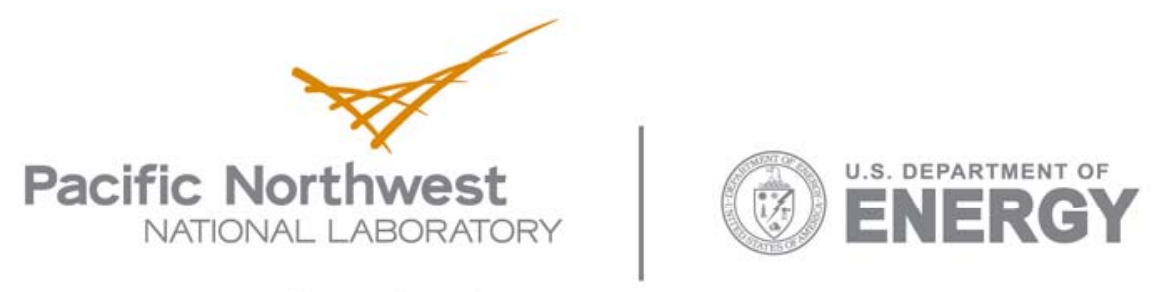

902 Battelle Boulevard

P.O. Box 999

Richland, WA 99352

1-888-375-PNNL (7665)

www.pnl.gov 